\title{
UNDERLYING INFLATION SEBAGAI INDIKATOR HARGA YANG RELEVAN DENGAN KEBIJAKAN MONETER: Sebuah Tinjauan Untuk Indonesia
}

\author{
Wijoyo Santoso dan Reza Anglingkusumo *)
}

Untuk melihat keberhasilan kebijakan moneter dalam mengendalikan inflasi, indikator harga yang digunakan selama ini adblah indeks harga konsumen atau IHK karena indikator ini dapat tersedia lebih cepat dibandingkan indikator harga lainnya seperti indeks harga perdagangan besar (IHPB) dan PDB deflator. Wblaupun IHK menupakan pilihan terbaik saat ini sebagai indeks harga yang paling relevan untuk melihat efektivitas kebijakan moneter, namu IHK mengandung kelemahan yaitu noise yang dapat mengganggu judgement kebijakan moneter. Beberapa unsur noise dalam IHK tersebut adalah faktor-faktor seperti kenaikan biaya inat prodksi (misalnya melalui pass through depresiasi nilai tukar dan kenaikan harga komoditi input untuk industri), kenaikan biaya enerji dan transportasi, kenaikan biaya distribusi domestik (second stage pass through dari depresiasi nilai tukar), kebijakan fiskal, faktor non-ekonomi (misalnya, kerusuhan sosial, bencana banjir, gempa bumi, gejala El-Nino, dan kebakaran hutan), administered prices, dan ketidakseimbangan serta inefisiensi dalam struktur industri. Semua faktor-faktor ini tidak memiliki relevansi dengan kebijakan moneter.

Oleh karena itu, telah dilakukan pengukuran underlying inflation yaitu laju inflasi yang ditunnkan dari inflasi IHK dengan mengeluarkan unsur noise dalam keranjang IHK. Terdapat beberapa metode untuk membersihkan IHK dari faktorfaktor tersebut antara lain metode specific adjustment, adjustment by exclusion, dan pemangkasan (trimmed method). Dengan mengeluarkan unsur noise dalam inflasi $\mathbb{H K}$ tersebut, yang tersisa adalah laju inflasi yang lebih disebabkan oleh tekanan kekuatan-kekuatan fundamental dari sisi pemintaan seperti interaksi antara ekspektasi masyarakat, jumlah uang yang beredar, dan siklus penggunaan kapasitas produksi. Dengan demikian, underlying inflation dapat menjadi proxy untuk inflasi yang disebabkan oleh sisi pemintaan yang secara teoritis dekat dan relevan dengan kebijakan moneter. Dalam kaitannya dengan penetapan laju inflasi sebagai target tunggal kebijakan moneter (inflation targeting), underlying inflation dapat berperan sebagai nominal anchor yang menjadi patckan bagi ekspektasi inflasi dan policy stance bank sentral yang kemudian diikuti oleh dunia usaha. Oleh karena itur sebagaimana di beberapa negara seperti Selandia Banu, Australia, Inggris, dan Kanada yang sudah menggunakan underlying inflation sebagai sasaran tunggal (single target), Bank Indonesia seharusnya menggunakan underlying inflation sebagai indikator dalam rangka memonitor efektivitas kebijakan monetemya.

Tulisan ini bermaksud memberikan gambaran pada pembaca mengenai konsep dan pengukuran underlying inflation serta implikasinya terhadap kebijakan moneter dan kaitannya dengan penetapan inflasi sebagai sasaran tunggal kebijakan moneter di Indonesia. Bagian pertama adalah pendahuluan yang meliputi latar belakang dilakukannya penelitian mengenai underlying inflation sebagai indeks harga yang relevan dengan kebi jakan moneter. Bagian kedua akan menyediakan landasan konseptual penelitian indikator harga yang relevan dengan kebijakan moneter. Pada bagian ketiga akan diuraikan mengenai metode-metode pengukuran underlying inflation. Di bagian keempat akan dipaparkan mengenai hasil-hasil dari penelitian indeks harga yang relevan dengan kebi jakan moneter, khususnya yang berkaitan dengan underlying inflation. Selanjutnya di bagian kelima akan diulas mengenai berbagai pelajaran yang dapat ditarik dari eskalasi krisis moneter terhadap penggunaan inflasi IHK sebagai indikator harga untuk mengukur efektifitas kebijakan moneter. Akhimiya, bagian keenam akan menyimpulkan tulisan ini sekaligus menyampaikan beberapa saran untuk penelitian lebih lanjut yang berkaitan dengan penggunaan underlying inflation dalam skim inflation targeting.

*) Wijoyo Santoso : Peneliti Ekonomi, Bagian Studi Sektor Riil, UREM, BI, Email: wijoyo_s@bi.go.id

Reza Angingkusumo : Asisten Peneliti Ekonomi, Bagian Studi Sektor Riil, UREM, BI, Email: bigsix@cbn.net.id Penulis mengucapkan terimakasih untuk diskusi dan komentar dari Hotbin Sigalingging, Kepala Bagian Studi Sektor Riil, UREM-BI, dan Noor Yudanto, Peneliti Ekonomi Yunior, Bagian Studi Sektor Riil, UREM-BI. 
Pendahuluan

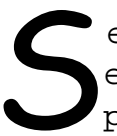
eiring dengan semakin menyatunya perekonomian nasional ke dalam tatanan ekonomi dunia, maka iklim ketidakpastian yang menjadi ciri dalam dinamika perekonomian global pun harus dihadapi oleh perekonomian Indonesia. Iklim ketidakpastian tersebut, terutama yang berkaitan dengan perubahan pada nilai tukar sebagian akan tercermin sebagai ketidakpastian perubahan harga-harga barang dalam masyarakat. Dalam jangka panjang, ketidakpastian harga akan menyulitkan pelaku ekonomi domestik maupun internasional untuk melakukan perencanaan kegiatan konsumsi, produksi, dan distribusinya, sehingga dapat menghambat pertumbuhan ekonomi.

Dari sisi domestik, laju inflasi dapat disebabkan oleh beberapa faktor yang saling terkait yaitu ekspektasi masyarakat terhadap laju inflasi, jumlah likuiditas yang beredar dalam perekonomian, tingkat penggunaan kapasitas usaha, dan faktor musiman. Dalam kaitannya dengan nilai tukar, tekanan domestik pada inflasi dapat pula disebabkan oleh kenaikan biaya produksi dan distribusi domestik sebagai akibat dari depresiasi dan gejolak pada nilai tukar. Lebih dari itu, inefisiensi dan ketidakseimbangan pada struktur fundamental mikro-ekonomi, khususnya di sektor-sektor yang erat kaitannya dengan produksi dan distribusi, dapat memperdalam dan memperpanjang tekanan pada laju inflasi terutama jika terjadi gejolak berkelanjutan pada faktor eksternal (khususnya nilai tukar) ${ }^{1}$.

Semua hal diatas mencerminkan kompleksitas dalam pengendalian dan stabilisasi laju inflasi melalui kebijakan moneter yang menjadi tugas pokok Bank Indonesia. Inflasi ternyata bukan semata-mata disebabkan oleh jumlah uang beredar sebagaimana yang ditekankan oleh Nobelaurate Profesor Milton Friedman. Sehingga, secara teknis dalam hubungannya dengan kebijakan moneter, Bank Indonesia dituntut untuk mengidentifikasi suatu indeks harga yang relevan dengan kebijakan moneter, yaitu indeks harga yang dapat dikendalikan melalui pengelolaan jumlah uang yang beredar. Indeks harga tersebut selanjutnya menjadi suatu patokan (anchor) dalam implementasi kebijakan moneter.

\section{Landasan Konseptual}

Sebagaimana telah disinggung diatas, kompleksitas pengendalian inflasi telah menyebabkan perlunya Bank Indonesia mengidentifikasi indikator harga yang relevan dengan kebijakan moneter. Secara teknis hal ini berarti mencari suatu indeks harga yang perilakunya secara statistik menceminkan policy stance Bank Indonesia mengenai jumlah likuiditas moneter dalam perekonomian. Untuk itu, Bank Indonesia perlu untuk pertamatama melakukan pembedahan terhadap beberapa indikator harga agregat seperti inflasi IHK dan IHPB menjadi beberapa kelompok, untuk diuji secara statistik keterkaitan perilaku dinamis jangka pendek dan panjangnya (relevansinya) dengan kebijakan moneter. Oleh karena itu pada sub-pembahasan ini akan diuraikan mengenai landasan konseptual yang digunakan dalam desain penelitian yang dilakukan oleh Bank Indonesia.

Secara statistik, dalam hubungannya dengan kebijakan moneter untuk

1 Kesimpulan dari pertemuan ESCAP ke-32 di Bangkok, Thailand misalnya menyebutkan bahwa pendalaman krisis di Asia, khususnya Indonesia, terutama disebabkan oleh struktur sektor riil yang tidak seimbang dan inefisien. 
pengendalian dan stabilisasi laju inflasi, dapat dilakukan pemilahan terhadap indikator inflasi agregat, seperti inflasi IHK dan IHPB, menjadi laju inflasi kelompok barang, misalnya kelompok makanan, sandang, perumahan, aneka barang, food \& energy ${ }^{2}$, nonfood \& non-energy ${ }^{3}$, administered dan non-administered ${ }^{4}$, traded dan non-traded ${ }^{5}$, IHPB sektoral ${ }^{6}$, IHPB ekspor ${ }^{7}$, dan IHPB impor ${ }^{8}$. Dengan melakukan pemilahan-pemilahan seperti ini, maka dapat dilakukan pengujian statistik yang lebih mendetil dan terfokus mengenai kaitan antara kebijakan pengendalian uang beredar dengan laju inflasi. Karena, bisa jadi perilaku indeks harga secara agregat, misalnya inflasi IHPB agregat, tidak mencerminkan stance kebijakan moneter, tetapi beberapa komponen sektoralnya seperti IHPB sektor industri, ekspor, dan pertanian mencerminkan.

Selanjutnya, khusus untuk laju inflasi IHK, pemilahan dapat pula dilakukan atas sifat dari inflasi $\mathbb{H K}$, yaitu sifat permanen dan temporer. Secara lebih rinci, laju inflasi IHK yang bersifat pemanen adalah laju inflasi yang disebabkan oleh meningkatnya tekanan permintaan terhadap barang dan jasa (permintaan agregat) dalam perekonomian, sehingga walaupun inflatoir dapat menambah pada pertumbuhan ekonomi nasional dalam jangka panjang. Beberapa faktor yang dapat menjadi penyebab perubahan laju inflasi yang bersifat pemanen tersebut adalah interaksi antara ekspektasi masyarakat terhadap laju inflasi, jumlah uang yang beredar dalam masyarakat, faktor siklus kegiatan usaha (misalnya tingkat penggunaan kapasitas produksi dan tingkat akumulasi cadangan produksi atau inventory), dan tekanan permintaan musiman (misalnya hari raya keagamaan, musim panen, dan dimulainya tahun ajaran baru) .

Komponen laju inflasi yang bersifat temporer dilain pihak, adalah komponen laju inflasi yang lebih disebabkan oleh adanya gangguan sesekali (one time shocks) pada laju inflasi. Beberapa faktor yang dapat menyebabkan terjadinya gejolak sementara tadi adalah kenaikan biaya input produksi dan distribusi (misalnya melalui depresiasi nilai tukar dan kenaikan harga komoditi input untuk industri), kenaikan biaya enerji dan transportasi, kebijakan fiskal, dan faktor non-ekonomi (seperti kerusuhan sosial, bencana banjir, gempa bumi, dan kebakaran hutan). Sedikit catatan perlu disampaikan disini bahwa faktor-faktor tersebut dapat menyebabkan tekanan inflatoir yang berkepanjangan jika terdapat struktur mikro fundamental yang tidak efisien dan tidak seimbang dalam perekonomian, khususnya struktur disektor produksi dan distribusi.

Dalam hubungannya dengan kedua sifat dari inflasi IHK diatas, Bank Indonesia kemudian perlu untuk mengukur komposisi antara komponen laju inflasi yang bersifat

2 Laju inflasi food dan energy adalah laju inflasi barang-barang yang dikategorikan sebagai bahan pangan dan bahan bakar dalam keranjang IHK.

3 Laju inflasi non-food dan non-energy adalah laju inflasi barang-barang diluar bahan pangan dan bahan bakar.

4 Laju inflasi administered adalah laju inflasi barang-barang yang harganya ditetapkan (dipengaruhi) oleh pemerintah melalui subsidi (misalnya beras, gula pasir, dan minyak goreng), sedangkan non-administered adalah laju inflasi barangbarang yang harganya tidak ditetapkan (dipengaruhi) oleh pemerintah.

5 Laju inflasi traded adalah laju inflasi barang-barang yang diperdagangkan dengan luar negeri, sedangkan laju inflasi non-traded adalah laju inflasi barang-barang yang tidak diperdagangkan dengan luar negeri.

6 Laju inflasi IHPB sektoral adalah laju inflasi barang perdagangan besar menurut sektor usaha, misalnya pertanian, pengolahan, pertambangan, dan sebagainya.

7 Laju inflasi IHPB ekspor adalah laju inflasi barang perdagangan besar yang diekspor.

8 Laju inflasi IHPB impor adalah laju inflasi barang perdagangan besar yang diimpor. 
permanen yang disebabkan oleh tekanan permintaan agregat dalam perekonomian dan yang bersifat temporer yang lebih disebabkan oleh one time events (gejolak temporer). Demikian halnya karena komponen laju inflasi yang permanen adalah komponen yang disebabkan oleh interaksi beberapa faktor yang diantaranya adalah jumlah uang yang beredar dalam perekonomian. Dalam hal ini, Roger (1995) telah berargumen bahwa laju inflasi yang permanen adalah laju inflasi yang relevan dengan kebijakan moneter. Dua alasan yang dikemukakan mengenai hal ini dirangkum oleh Claus (1997) yaitu: pertama, pada dasarnya pengendalian komponen laju inflasi yang temporer adalah diluar kemampuan otoritas moneter. Walaupun begitu, otoritas moneter dapat mengeluarkan kebijakan untuk meredam efek lanjutan (second round effect) dari gejolak temporer tersebut, yang akan tercemin dalam laju inflasi jangka menengah (medium tem inflation) atau underlying inflation. Kedua, jika jelas bahwa gejolak inflasi lebih disebabkan oleh one-time events, maka semakin lemah argumen yang menyatakan bahwa perlu dikeluarkan kebijakan moneter untuk meredam pertumbuhan ekonomi dan penyerapan tenaga kerja dalam jangka pendek guna menstabilkan gejolak pada inflasi.

Untuk mengukur laju inflasi yang bersifat permanen diatas, telah dilakukan pengukuran terhadap laju underlying inflation Indonesia. Underlying inflation adalah laju inflasi yang mencerminkan kecenderungan fundamental pertumbuhan harga-harga agregat jangka menengah (medium term inflation). Underlying inflation berbeda dari laju inflasi aktual karena didalam keranjang pembentuknya telah dikeluarkan unsur noise (laju inflasi temporer). Akibat dari dikeluarkannya unsur noise tersebut diperoleh suatu ukuran inflasi yang merupakan sinyal dari tekanan kekuatan-kekuatan yang lebih fundamental dalam perekonomian, seperti ekspektasi, jumlah uang beredar, siklus penggunaan kapasitas prockuksi (output gap), dan faktor permintaan musiman. Selanjutnya, semua unsur dari tekanan fundamental ini ekuivalen dengan tekanan permintaan agregat dalam perekonomian, sehingga underlying inflation dapat pula didefinisikan sebagai laju inflasi dari sisi permintaan agregat.

\section{Metodologi Pengukuran Underlying Inflation}

Merujuk pada kajian-kajian akademis dan hasil studi banding di dua negara yaitu Australia dan Selandia Baru, maka secara umum dapat disimpulkan bahwa terdapat dua metode dalam pengukuran underlying inflation, yaitu metode judgemental dan non-judgemental ${ }^{9}$. Pengukuran dengan metode judgemental adalah pengukuran dengan mengeluarkan barang-barang dalam keranjang IHK yang inflasinya dinilai terlalu bergejolak (volatile), dipengaruhi oleh faktor musim geografis (seasonal), dan dipengaruhi oleh kebijakan pemerintah. Dalam diskusi dikalangan akademis maupun praktisi, terdapat dua teknik pengukuran dengan metode judgemental, yaitu teknik specific adjustment dan teknik adjustment by exclusion. Sedangkan untuk teknik non-judgemental digunakan teknik pemangkasan trimmed method, yang pada hakikatnya adalah minimisasi pengaruh noise pada series IHK dengan menggunakan suatu nilai kritikal tertentu yang selanjutnya hasil ukuran tersebut

9 Roger, Scott, 1995. Measures of Underlying Inflation in New Zealand, 1981-1995. RBNZ, September

10 Teknik ini lazim disebut sebagai limited influence estimator, dimana penilaian sepihak mengenai komponen mana yang harus dibuang dari IHK diminimisasi dengan menganggap setiap angka ekstrem (transitory outliers) sebagai gangguan (noise). 
diuji integritasnya secara statistik ${ }^{10}$.

Teknik specific adjustment merujuk pada teknik pengukuran dengan mengeluarkan angka pada komponen-komponen IHK yang besar perubahannya pada satu waktu tertentu dinilai mengganggu judgement kebijakan moneter, dimana gangguan-gangguan tersebut dapat bersumber dari perubahan rate pajak terhadap harga barang maupun perubahan mendadak pada harga-harga bahan baku produksi (price shodks), harga enerji dan biaya transportasi, serta kenaikan harga karena kelangkaan pasokan (supply shortage). Secara umum metode ini dianggap cukup baik jika besaran (magnitude) dan rentang waktu (timing) dari kejutan-kejutan diatas dapat diidentifikasi dengan informasi yang ada. Masalah utama yang dihadapi jika underlying inflation diukur dengan teknik ini adalah adanya kesulitan untuk melakukan identifikasi sumber perubahan harga jika efek dari sumber perubahan tersebut bersifat tidak langsung. Sebagai contoh, besaran dan waktu dari perubahan harga barang-barang impor di dunia mungkin dengan mudah dapat diidentifikasi, akan tetapi besaran dan waktu dari kejadian tersebut hingga mempengaruhi harga-harga barang konsumsi didalam negeri masih perlu diidentifikasi dan diestimasi lebih lanjut. Hal ini berakibat perlunya untuk melakukan estimasi besarnya pengaruh dari kenaikan harga impor tersebut (pass-through) pada setiap komponen IHK yang dinilai akan terpengaruh.

Teknik kedua dalam metode judgemental adalah adjustment by exclusion. Teknik ini membuang komponen tertentu dari indeks harga agregat yang perilakunya dinilai berbeda secara mendasar dari kecenderungan umumnya. Dengan membuang komponen-komponen tersebut, indeks yang dihasilkan dianggap sebagai indeks yang mencerminkan underlying inflation. Berbeda dari teknik specific adjustment, adjustment by exclusion tidak menetralisir pengaruh sumber perubahan harga yang ekstrem secara kasus-per-kasus, akan tetapi menghapus satu komponen tertentu dari indeks harga agregat. Penghapusan terhadap series komponen tersebut dilakukan setelah terlebih dahulu melakukan penilaian terhadap pencaran (frequency distribution) dari perubahan harga-harga. Dengan penilaian-penilaian tersebut dilakukan identifikasi secara sepihak terhadap tingkat gejolak dari suatu komponen. Jika komponen tersebut dinilai sangat bergejolak sepanjang satu periode tertentu maka komponen tersebut akan dikeluarkan dari keranjang IHK. Masalah utama yang dihadapi dalam pengukuran dengan teknik ini adalah adanya kesulitan untuk menentukan tingkat gejolak, mengingat panjang pendeknya periode pengukuran akan mempengaruhi persepsi pengukur mengenai tingkat gejolak.

Disamping kedua teknik judgmental diatas, ukuran underlying inflation dapat pula diperoleh dengan menggunakan metode non-judgemental yaitu teknik pemangkasan (trimmed method). Dengan teknik ini dilakukan pemangkasan terhadap keranjang IHK sehingga diperoleh suatu angka inflasi yang relatif bersih dari noise yang mengganggu judgement kebijakan. Pemangkasan dilakukan dengan berbagai nilai kritikal pemangkasan untuk memperoleh beberapa ukuran underlying inflation. Selanjutnya ukuran-ukuran tersebut dievaluasi dengan menggunakan berbagai konsep statistik inferensial, seperti standar deviasi dan autocorrelation, serta dilakukan pula uji sebab-akibat (Granger Causality Test) untuk memilih ukuran yang relatif paling bersih dari unsur noise .

Secara formal dengan merujuk pada Bryan dan Cecchetti (1993) underlying inflation yang diukur dengan metode non-judgmental adalah minimalisasi dari unsur noise atau komponen non-permanen secara kuantitatif. Secara lebih spesifik, noise mengacu pada 
gejolak tidak permanen (temporaray shocks) pada pergerakan harga-harga pembentuk indeks harga umum, yang tidak boleh sampai mempengaruhi judgement dari kebijakan moneter. Dampak dari nise adalah ketidakakuratan perubahan jangka pendek inflasi dalam mencerminkan perilaku kecenderungan jangka panjangnya. Mengingat sifatnya yang transitory, maka analisa terhadap dampak noise pada pengukuran underlying inflation menjadi sangat penting. Karena jika Bank Indonesia akan menjadikan inflasi sebagai target kebijakan moneter, maka diperlukan adanya suatu batasan-batasan (bands) target inflasi yang relatif bersih dari noise. Alasan lain adalah agar dapat dibuat suatu penafsiran yang reliable terhadap pergerakan laju inflasi medium term.

Beberapa sumber dari noise yang diidentifikasi di beberapa negara yang menggunakan underlying inflation sebagai sasaran kebijakan moneter ${ }^{11}$ adalah: (1) Perubahan harga-harga yang hanya berlangsung pada musim-musim tertentu (seasonal), (2) Perubahan yang besar dan mendadak pada harga sumber daya secara luas (broadbased resource shock) yang disebabkan oleh depresiasi nilai tukar, dinamika dalam perdagangan internasional, dan atau kenaikan harga enerji, (3) Perubahan 'rate' pajak tak langsung (indirect tax-rate), dan (4) Penyesuaian-penyesuaian harga yang besar dan tak berkala yang dilakukan baik oleh sektor swasta maupun pemerintah.

Secara konseptual dengan berasumsi bahwa setiap noise adalah transitory atlies ${ }^{12}$ yang tidak berpotensi untuk meninggalkan bekas permanen pada basic trend inflasi maka dengan membuang atliers akan diperoleh suatu ukuran harga yang yang mencerminkan kecenderungan jangka menengah dari perubahan harga-harga yang sebenarnya, atau underlying inflation ${ }^{13}$. Di Australia misalnya, ditemui adanya sasaran inflasi jangka menengah (medium-term inflation target) yang diumumkan kepada masyarakat. Berdasarkan kesepakatan antara Pemerintah Australia dengan the Reserve Bank of Australia (RBA) telah ditetapkan suatu kisaran medium-term inflation tersebut, yaitu sebesar 2-3\%. Sasaran kisaran 2-3\% ini diterjemahkan sebagai sasaran agar kecenderungan umum dari laju kenaikan harga-harga konsumen (broad central tendency for inflation), atau rata-rata kenaikan harga-harga konsumen sepanjang satu periode tertentu adalah sebesar 2-3\%. Oleh karena itu, sasaran ini bukanlah sasaran angka inflasi jangka pendek yang harus dicapai, melainkan suatu sasaran yang akan mencerminkan kecenderungan angka inflasi yang secara material tidak mengganggu keputusan

11 Diskusi mengenai faktor noise dapat dilihat pada Reserve Bank of Australia Bulletin 1994,; Measuring Underlying Inflation, Agustus; dan Bryan, Michael F. dan Cecchetti, Stephen G. 1993, Measuring Core Inflation, Federal Reserve Bank of Cleveland, Working Paper \# 9304, June; serta Roger, Scott, 1995. Measures of Underlying Inflation in New Zealand, 1981-1995. RBNZ, September.

12 Transitory outliers dalam hal ini didefinisikan sebagai gejala ekstrem yang berlangsung tidak terlalu lama dan tidak secara permanen merubah kecenderungan jangka panjang harga walaupun gejala tersebut berukuran besar . Bryan dan Cecchetti melihat bahwa komponen-komponen transitory ini harus dikeluarkan dari pengukuran underlying inflation sehingga diperoleh suatu angka laju inflasi yang hanya mencerminkan perilaku komponen-komponen yang persistent dan permanent. Selanjutnya dengan berasumsi bahwa velocity of money selalu konstan maka angka laju inflasi yang bersih dari komponen transitory tersebut adalah ukuran dari inflasi moneter (monetary inflation) ( Bryan, Michael F. dan Cecchetti, Stephen G. 1993, Measuring Core Inflation, Federal Reserve Bank of Cleveland, Working Paper \# 9304, June.

13 Beberapa istilah telah dipergunakan untuk menjelaskan konsep kecenderungan dalam definisi underlying rates of inflation ini. Inggris dan Australia menyebut kecenderungan "riil" ini sebagai medium term rates of inflation. Selandia Baru menyebutnya sebagai kecenderungan utama jangka panjang (long run central tendency of inflation). Kanada menggunakan istilah trend dasar dari harga-harga agregat (basic trend of aggregate prices) 
keuangan dari dunia usaha dan rumah tangga konsumen (household consumers). Di Australia, kisaran angka sasaran medium-tem inflation tersebut dikenal dengan sebutan the Treasury Underlying Rate (Australian Bureau of Statistics) atau Underlying CPI yang ditetapkan oleh RBA, dan oleh kalangan dunia usaha dilihat sebagai sasaran inflasi bank sentral (the RBA inflation target). Perilaku dari angka underlying inflation ini sejak dikeluarkannya lima tahun yang lalu telah berperan sebagai anchor bagi inflation expectations di Australia yang juga merupakan indikator awal dari perilaku inflasi jangka pendek dimasa datang (predictor of short-nun future course of inflation) ${ }^{14}$.

Disamping itu, penetapan sasaran underlying inflation diatas juga digunakan untuk mengimplementasikan kebijakan moneter yang forward-looking. Instrumen kebijakan moneter akan disesuaikan untuk menjaga agar proyeksi medium-term inflasi RBA tetap pada kisaran 2-3\%. RBA melakukan pengetatan moneter sebelum adanya kenaikan inflasi diatas 3\% dan tekanan kebijakan tidak akan dikurangi sebelum angka medium term tersebut berada dibawah 3\%. Jika terjadi perubahan laju inflasi jangka menengah yang tidak diantisipasi sebelumnya, RBA akan melakukan penyesuaian kebijakan untuk menurunkan angka tersebut secepatnya tergantung dari penyebabnya. Dengan kata lain RBA tidak akan membiarkan perubahan pada komponen persistent dalam inflasi untuk secara permanen tercermin dalam laju perubahan harga-harga.

Di Selandia Baru salah satu elemen penting dalam mekanisme kerja Bank Sentralnya adalah terikatnya perilaku kebijakan dari The Reserve Bank of New Zealand (RBNZ) terhadap kewajiban untuk secara berkala memberi laporan kepada khalayak tentang progress dari pelaksanaan the Policy Targets Agreement (PTA). Kesepakatan dalam PTA ini memberi arah bagi RBNZ dalam kegiatannya untuk menjaga stabilitas harga-harga umum agar tetap dalam target bands yang telah disepakati bersama dengan Kementerian Keuangan Selandia Baru, yaitu pada kisaran pertumbuhan CPI tahunan sebesar 0\% - 2\%. Dengan kisaran target bands tersebut RBNZ bertanggung jawab atas kebijakan moneter yang diarahkan untuk menahan agar perubahan harga temporer tidak meninggalkan bekas permanen pada trend jangka panjang inflasi. Untuk itu PTA memberi suatu petunjuk mengenai kondisikondisi prinsip yang dikategorikan sebagai temporary disturbances dan dapat menjadi es cape clause RBNZ dalam merumuskan kebijakan moneter untuk sasaran pengendalian hargaharga ${ }^{15}$. Hal-hal tersebut adalah: (1) Adanya perubahan tingkat suku bunga yang secara mendasar dapat menyebabkan penyimpangan trend jangka panjang Consumer Price Index (CPI) yang mengeluarkan komponen suku bunga (CPI excl. interest components); (A) Adanya perubahan mendasar yang terjadi hanya sekali (once-off) pada tingkat harga-harga umum yang dapat mempengaruhi trend jangka panjangnya yang dapat terjadi karena perubahan terms of trade, perubahan sistem tarif dan pungutan pemerintah, dan perubahan tarif pajak; dan (3) Adanya perubahan mendasar yang terjadi hanya sekali (once-off) pada perubahan harga relatif (relative price changes); serta, (4) Bencana alam dan serangan hama dan penyakit pada tanaman pangan dan peternakan.

14 Mengenai hal ini Gubernur Ian MacFarland dari RBA menyebutkan bahwa kinerja dari the underlying CPI, yang disusun oleh the Australian Bureau of Statistics dan RBA sebagai rujukan (anchor) secara konsisten berada dalam target kisaran 2\% - 3\% dan telah menolong dalam mempersempit spread antara yields obligasi jangka panjang di Australia dan jenis obligasi yang sama di negara-negara lain.

15 Kondisi-kondisi prinsip yang dilaporkan dalam makalah ini sesuai dengan the Policy Targets Agreement of 19 December, 1992 yang tercantum menggantikan section 9(4) dari The Reserve Bank of New Zealand Act tahun 1989. 
Pengukuran underlying inflation secara non-judgemental di Australia mengacu pada metodologi pemangkasan sebagaimana yang telah disinggung terdahulu. Metode yang demikian ini ditempuh dengan asumsi bahwa angka underlying inflation yang ideal untuk kebijakan moneter adalah angka yang menangkap kecenderungan siklikal dan trend dari tingkat harga umum. Oleh karena itu unsur volatilitas, musiman, dan policy disturbances harus dikeluarkan dari pengukuran inflasi. Metode pemangkasan ini digunakan juga di Selandia Baru untuk mengukur underlying inflation di negara tersebut.

Di Indonesia, pengukuran underlying inflation dilakukan dengan pemangkasan terhadap data IHK-Indonesia yang melibatkan series IHK bulanan dari bulan Mei 1990 sampai dengan bulan Mei 1998. Langkah-langkah dalam prosedur pemangkasan tersebut adalah sebagai berikut:

1. Mengumpulkan series bulanan indeks IHK untuk setiap barang. Series ini diolah oleh Bagian Statistik Sektor Riil dan Keuangan Pemerintah (SRKP), Urusan Statistik Ekonomi dan Moneter (USEM) Bank Indonesia. Dari data yang tersedia diperoleh suatu periode pengukuran, yaitu dari bulan Mei 1990 sampai dengan bulan Mei 1998. ${ }^{16}$ Untuk setiap bulan observasi, seluruh komoditi yang dipakai dalam menghitung IHK berikut bobotnya masing-masing (sesuai dengan bobot yang dihitung oleh Bagian SRKP, USEM, Bank Indonesia) digunakan dalam pengukuran. Total keseluruhan komoditi tersebut berjumlah 337 komoditi.

2. Selanjutnya dihitung laju inflasi dari setiap barang dan dilakukan perhitungan inflasi terbobot bulanannya.

3. Dilakukan pensortiran laju inflasi bulanan terbobot untuk setiap barang sehingga data berurutan dari yang terbesar ke terkecil.

4. Berdasarkan urutan yang tercipta dilakukan pemangkasan pada angka-angka ekstrem teratas dan terbawah dengan menggunakan beberapa nilai kritikal, yaitu 10\%, 15\%, 20\%, $25 \%$, 30\%, 35\%, $40 \%$, 45\%, dan 50\%.

5. Ukuran-ukuran yang diperoleh kemudian diuji tingkat kebersihannya dari unsur noise dengan menguji hubungan sebab akibat antara inflasi barang-barang yang terpangkas terhadap inflasi yang sudah terpangkas. Ukuran dianggap bersih dari noise jika inflasi barang-barang yang terpangkas tidak menyebabkan inflasi barang-barang yang sudah terpangkas.

6. Akhimya, dari ukuran-ukuran yang telah diseleksi diatas dicari lagi ukuran yang memiliki gejolak terendah (standard deviation terendah) tapi memiliki kadar informasi tertinggi (autocorrelation tertinggi).

Grafik 1 menggambarkan laju inflasi underlying inflation yang diukur dengan metode pemangkasan diatas dibandingkan dengan laju inflasi IHK. Dari hasil perhitungan, secara historis komponen permanen dari inflasi IHK secara rata-rata tidaklah lebih dari 20-30\% dari total IHK. Ini memberi implikasi bahwa secara rata-rata paling sedikit 70-80\% dari laju inflasi IHK disebabkan oleh noise (komponen tidak permanen). Bagi pelaksanaan

16 Untuk saat ini angka underlying inflation bulan April dan Mei 1998 masih merupakan angka sementara yang dipangkas berdasarkan 30 sub-kelompok barang dalam IHK. 
Grafik 1. Laju Inflasi IHK, Underlying Inflation, dan Noise

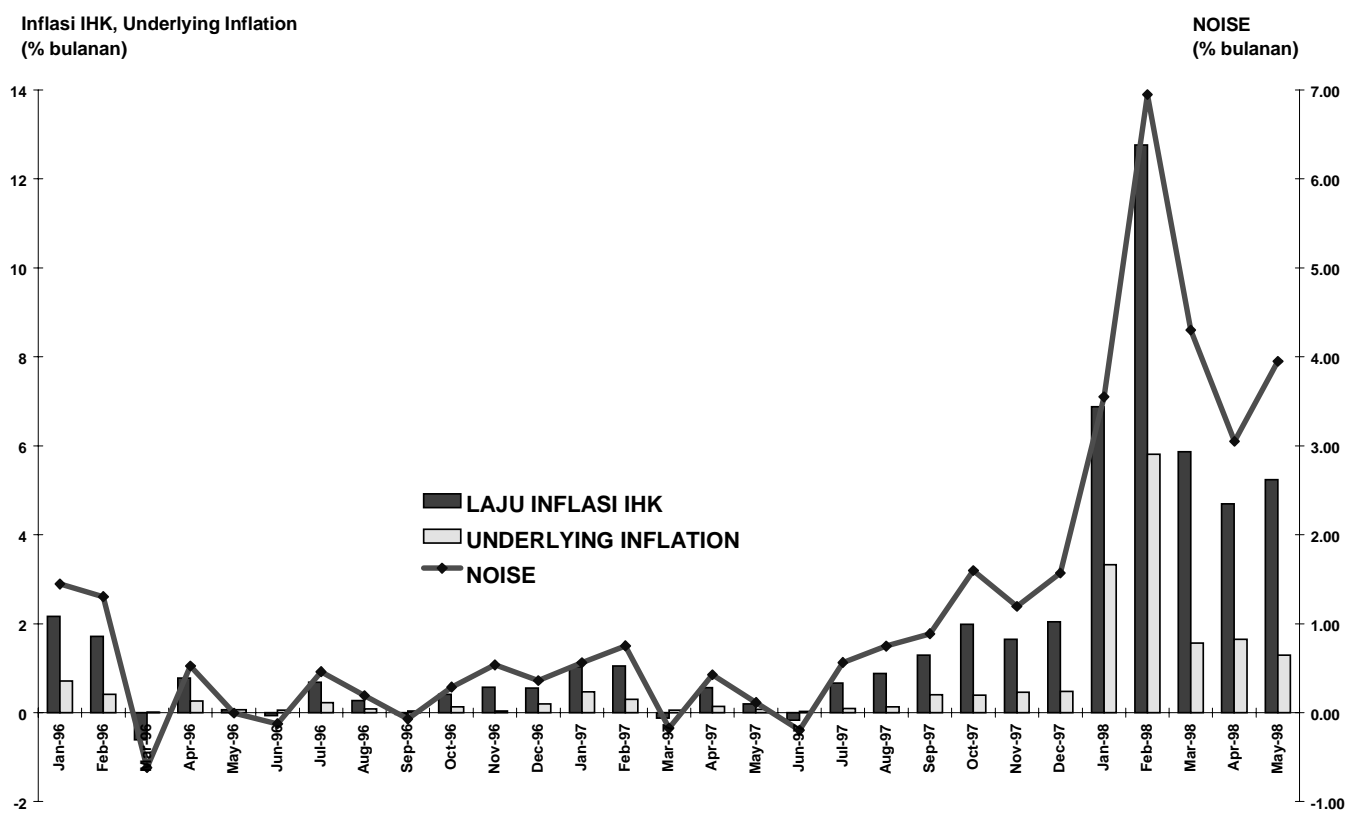

kebijakan moneter hal ini berarti pula bahwa terdapat setidaknya 70\% dari laju inflasi IHK yang tidak relevan dengan kebijakan moneter. Demikian halnya karena sebagian besar dari laju inflasi IHK tersebut lebih disebabkan oleh faktor-faktor yang berada diluar jangkauan kebijakan moneter, misalnya kenaikan harga barang-barang impor baik karena depresiasi nilai tukar maupun karena dinamika dalam perdagangan dunia, kenaikan harga enerji serta biaya transportasi yang menyertainya, gejolak musim geografis, kenaikan harga barang input domestik, dan kelangkaan pasokan barang karena faktor-faktor non-ekonomis.

Walaupun demikian pendapat bahwa hanya 20-30\% dari komponen inflasi IHK yang relevan dengan kebijakan moneter masih perlu dibuktikan secara statistik. Oleh karena itu, dalam sub-pembahasan berikut akan dipaparkan hasil dari penelitian indeks harga yang relevan dengan kebijakan moneter.

\section{Hasil Penelitian}

Sebelum lebih jauh mengulas mengenai hasil penelitian ini, maka terlebih dahulu akan disampaikan secara sekilas mengenai metodologi yang digunakan dalam penelitian ini. Dalam garis besarnya, penelitian dilakukan dengan melakukan uji kedekatan hubungan statistik antara inflasi agregat berikut komponen-komponennya dengan besaran-besaran moneter . Inflasi agregat yang diteliti adalah laju inflasi IHK , laju inflasi IHPB, dan PDB deflator, sedangkan komponen inflasi yang diuji adalah kelompok makanan, sandang, perumahan, aneka barang, food \& energy , non-food \& non-energy' administered dan non-administered, traded dan non-traded, IHPB sektoral , IHPB ekspor, dan IHPB impor. Telaah yang lebih khusus 
dilakukan terhadap underlying inflation yang merupakan komponen permanen dalam inflasi IHK guna menampilkan relevansi indikator harga ini dengan kebijakan moneter.

Untuk melakukan uji kedekatan diatas beberapa teknik analisa statistik telah digunakan secara simultan dan berurutan. Analisa dilakukan dengan melibatkan data tahunan untuk melihat hubungan jangka panjang, dan data bulanan untuk melihat hubungan jangka pendek. Teknik pertama yang digunakan adalah uji korelasi sederhana ${ }^{17}$, yaitu suatu uji statistik yang melihat kedekatan awal dan arah antara variabel-variabel yang diuji, misalnya inflasi kelompok makanan dengan pertumbuhan M0, inflasi kelompok sandang dengan pertumbuhan M2, dan seterusnya. Berdasarkan hasil uji korelasi sederhana tersebut dilakukan uji struktur $\operatorname{lag}^{18}$ untuk melihat secara historis lamanya suatu variabel berpengaruh terhadap variabel yang lainnya, misalnya menguji sampai berapa bulan pertumbuhan M0 mempengaruhi laju inflasi IHK, berapa lama pertumbuhan M2 akan tercemin pada laju inflasi IHPB, dan seterusnya. Setelah itu, dilakukan analisa hubungan sebab akibat ${ }^{19}$ antara dua variabel, untuk melihat variabel mana yang menjadi penyebab diantara dua variabel yang diuji, misalnya apakah pertumbuhan M2 menyebabkan inflasi kelompok food \& energy, atau sebaliknya. Kemudian, setelah arah hubungan diketahui, dilakukan uji kekuatan transmisi ${ }^{20}$ untuk melihat seberapa lama kekuatan pengaruh suatu variabel terhadap variabel lainnya untuk jangka waktu kedepan, misalnya selama berapa bulan kedepan kebijakan meningkatkan jumlah M0 yang beredar akan mempengaruhi laju inflasi IHK. Akhirnya, setelah kekuatan transmisi diketahui dilakukan taksiran kedekatan hubungan dengan menggunakan suatu persamaan statistik sehingga diperoleh derajat kekuatan hubungan antara variabel-variabel yang independen dengan variabel yang dependen ${ }^{21}$. Sebagai misal, disusun suatu persamaan bahwa laju underlying inflation ditentukan oleh ekspektasi, pertumbuhan M0, pertumbuhan M1, pertumbuhan $\mathrm{M} 2$, dan output gap ${ }^{22}$, maka derajat kepekaan akan diukur dari tingkat signifikansi ${ }^{23}$ dari variabel-variabel tersebut dalam mempengaruhi underlying inflation.

Berdasarkan metodologi diatas diperoleh hasil sebagai berikut:

1. Untuk pengendalian inflasi melalui pengelolaan jumlah uang kertas dan logam yang beredar di masyarakat (MO), indikator harga yang paling relevan dan dapat dijadikan anchor adalah laju inflasi IHK agregat dan laju inflasi kelompok food \& energy dalam keranjang IHK .

2. Untuk pengendalian inflasi melalui pengelolaan jumlah uang giral yang diciptakan oleh

17 Uji korelasi sederhana dilakukan dengan membuat simple correlation matrix yang melibatkan semua variabel yang diuji dalam penelitian.

18 Uji struktur lag dilakukan dengan melakukan analisa cross correlogram terhadap semua variabel yang diuji dalam penelitian.

19 Uji hubungan sebab akibat dilakukan dengan melakukan Granger Causality Test terhadap semua variabel yang diuji dalam penelitian.

20 Uji kekuatan transmisi dilakukan dengan melakukan analisa Variance Decomposition berdasarkan hasil uji sebab akibat.

21 Taksiran kedekatan statistik dilakukan dengan membuat model persamaan polynomial distributed lag dan model structural dynamics.

22 Output gap ditaksir dengan melakukan Hodrick-Prescott filtering terhadap series PDB kuartalan deseasonalized yang diinterpolasi menjadi data bulanan.

23 Tingkat signifikasi yang mencerminkan tingkat kedekatan diukur dengan ranking $t$-statistics dari setiap independen variabel yang terlibat dalam pengujian. 
sistem perbankan ditambah dengan uang kertas dan uang logam yang beredar diluar Bank Indonesia (MI), indikator harga yang paling relevan dan dapat dijadikan anchor adalah PDB deflator.

3. Untuk pengendalian inflasi melalui pengelolaan M2, yaitu total jumlah Ml ditambah uang kuasi (tabungan dan deposito) di sistem perbankan, indikator harga yang paling relevan dan dapat dijadikan anchor adalah laju inflasi kelompok non-administered, nontraded, IHPB agregat dan underlying inflation .

4 Khusus untuk underlying inflation yang merupakan komponen IHK yang permanen dan menceminkan inflasi dari sisi permintaan agregat, terdapat indikasi statistik yang cukup kuat bahwa interaksi simultan antara ekspektasi masyarakat terhadap besarnya noise dalam inflasi, jumlah uang yang beredar, siklus penggunaan kapasitas produksi (output gap), dan tekanan permintaan musiman adalah faktor yang mempengaruhi dinamika underlying inflation terutama dalam kaitannya dengan ekskalasi krisis moneter.

5 Unsur noise dalam inflasi IHK banyak ditentukan oleh faktor gejolak pada nilai tukar (first stage pass through), kenaikan biaya produksi dan distribusi domestik (second stage pass through), kenaikan biaya enerji dan transportasi, kelangkaan barang pasokan (supply shortage), dan faktor musim geografis, sehingga tidak relevan dengan kebijakan moneter. Disamping itu, terdapat indikasi kuat bahwa unsur noise ditengah krisis moneter dapat menyebabkan perubahan struktural pada perilaku jangka panjang inflasi IHK yang juga berarti bahwa terdapat perubahan struktural yang cukup berarti di sisi penawaran dalam perekonomian sebagai akibat dari krisis moneter. Underlying inflation dilain pihak, mempunyai kecenderungan untuk tetap pada perilaku jangka panjangnya dimasa pra-krisis ${ }^{24}$

Beberapa catatan tambahan dapat disampaikan disini, yaitu:

1. Walaupun laju inflasi IHPB dan PDB deflator termasuk dalam indikator harga yang relevan dengan kebijakan moneter, akan tetapi mengingat ketersediaan data untuk menyusun kedua indikator ini sangatlah lambat, maka kegunaannya sebagai anchor kebijakan moneter menjadi tidak ada.

2. Iaju inflasi food \& energy walaupun dekat dengan pertumbuhan uang kertas dan logam yang beredar, tapi secara historis dinamika indikator ini cukup sarat dipengaruhi oleh faktor-faktor yang mempengaruhi noise dalam IHK, sehingga cukup besar kemungkinan bahwa indikator ini dapat mengganggu judgement kebijakan jika digunakan sebagai anchor.

3. Secara historis barang-barang yang membentuk underlying inflation sebagian besar juga dapat dikategorikan dalam kelompok inflasi non-administered dan non-traded. Oleh karena itu bagi kebijakan moneter, tampaknya underlying inflation adalah suatu indikator harga yang lebih komprehensif dalam fungsinya sebagai anchor.

\section{Beberapa Pelajaran dari Krisis Moneter}

Sebagaimana telah disinggung diatas, salah satu sasaran akhir dari kebijakan moneter adalah pengendalian inflasi yang dilakukan melalui pengelolaan jumlah uang beredar

\footnotetext{
24 Hasil penelitian dapat dilihat di Lampiran 2.
} 
secara hati-hati. Akan tetapi dengan terjebaknya perekonomian nasional kedalam krisis nilai tukar, perekonomian nasional kemudian memasuki krisis makro-moneter yang saat ini telah memasuki periode krisis (resesi) ekonomi makro yang dalam dan cukup berat, yang antara lain ditandai oleh terus melemahnya nilai tukar rupiah dan tingginya ekspektasi laju inflasi.

Dengan sedikit menengok ke belakang ke periode awal dari krisis moneter yaitu pada semester II / 1997, maka dapat dilihat bahwa seiring dengan adanya contagion effect dan krisis kepercayaan terhadap sustainability makro-fundamental perekonomian nasional, telah terjadi sudden capital outflows yang menekan nilai tukar Rp/USD. Dengan depresiasi yang kuat pada nilai tukar tersebut, telah berkembang suatu iklim ketidakpastian usaha di sektor riil. Para pengusaha mengalami kesulitan untuk menetapkan anggaran usahanya dan ini berpengaruh pada keputusan-keputusan usaha yang berkaitan dengan produksi dan distribusi. Implikasi langsung dari fenomena ini terhadap laju inflasi, adalah meningkatnya unsur noise dalam laju inflasi IHK melalui: (i) dampak depresiasi nilai tukar ke harga-harga (first stage pass through); (ii) penurunan pasokan barang-barang dalam perekonomian baik karena menurunnya jumlah barang-barang hasil produksi secara agregat; maupun oleh (iii) adjustment di sektor distribusi barang-barang karena penurunan pasokan barang kemudian menekan laba sebelum pajak para distributor, yang selanjutnya diterjemahkan menjadi meningkatnya biaya operasi per unit dan harga barang per-unit (second stage pass through).

Seiring dengan tekanan yang berasal dari depresiasi nilai tukar di atas, pada semester II/1997 juga diimplementasikan pencabutan subsidi bahan-bahan pokok diluar beras melalui BULOG yang mengakibatkan tekanan inflatoir pada komoditi-komoditi seperti gula pasir, minyak goreng, dan tepung terigu. Kemudian menjelang triwulan I / 1998 tekanan pada harga-harga ditambah lagi oleh datangnya faktor tekanan permintaan musiman seperti Hari Raya Natal dan Bulan Ramadhan.

Bersamaan dengan tekanan yang terjadi di sektor riil diatas, terjadi krisis kepercayaan terhadap sistem perbankan nasional sebagai akibat dari diimplementasikannya nota kesepakatan pertama dengan IMF mengenai restrukturisasi sistem perbankan melalui kebijakan likuidasi 16 bank. Dampak dari kebijakan likuidasi ini adalah terjadinya krisis kepercayaan terhadap sistem perbankan nasional yang diikuti oleh fenomena bank nun dimana masyarakat menarik dana simpanannya dari sistem perbankan. Dana yang ditarik tersebut kemudian sebagian dialihkan menjadi simpanan berdenominasi USD (flight to arrency) dan atau simpanan di bankbank asing (fligtt to qality), dan sebagian lainnya dikonsumsi untuk mengantisipasi kenaikan pada harga-harga sebagaimana yang terjadi di triwulan I/ 1998. Implikasi dari hal-hal tersebut adalah tekanan domestik pada nilai tukar Rp/USD, dimana permintaan terhadap mata uang USD terus meningkat, sementara itu pasokan USD cenderung berkurang sebagai akibat dari semakin dekatnya saat pembayaran utang luar negeri swasta yang jatuh tempo. Tekanan pada nilai tukar tersebut selanjutnya menambah pada iklim ketidakpastian usaha di triwulan I / 1998 yang sudah semakin terakumulasi semenjak triwulan IV / 1997.

Excessive depreciation nilai tukar Rp/USD dan meningkatnya iklim ketidakpastian usaha yang di akibatkannya di awal triwulan I / 1998 diatas telah menyebabkan semakin meningkatnya komponen biaya input dalam struktur biaya produksi nasional dan menurunnya minat produksi pada industri-industri di sektor riil. Hal ini kemudian memukul laba dari sektor-sektor yang berkaitan dengan distribusi sejalan dengan 
Grafik 2. Inflasi IHK, Underlying Inflation, Noise, dan Proporsi Underlying Inflation (dalam 이anan)

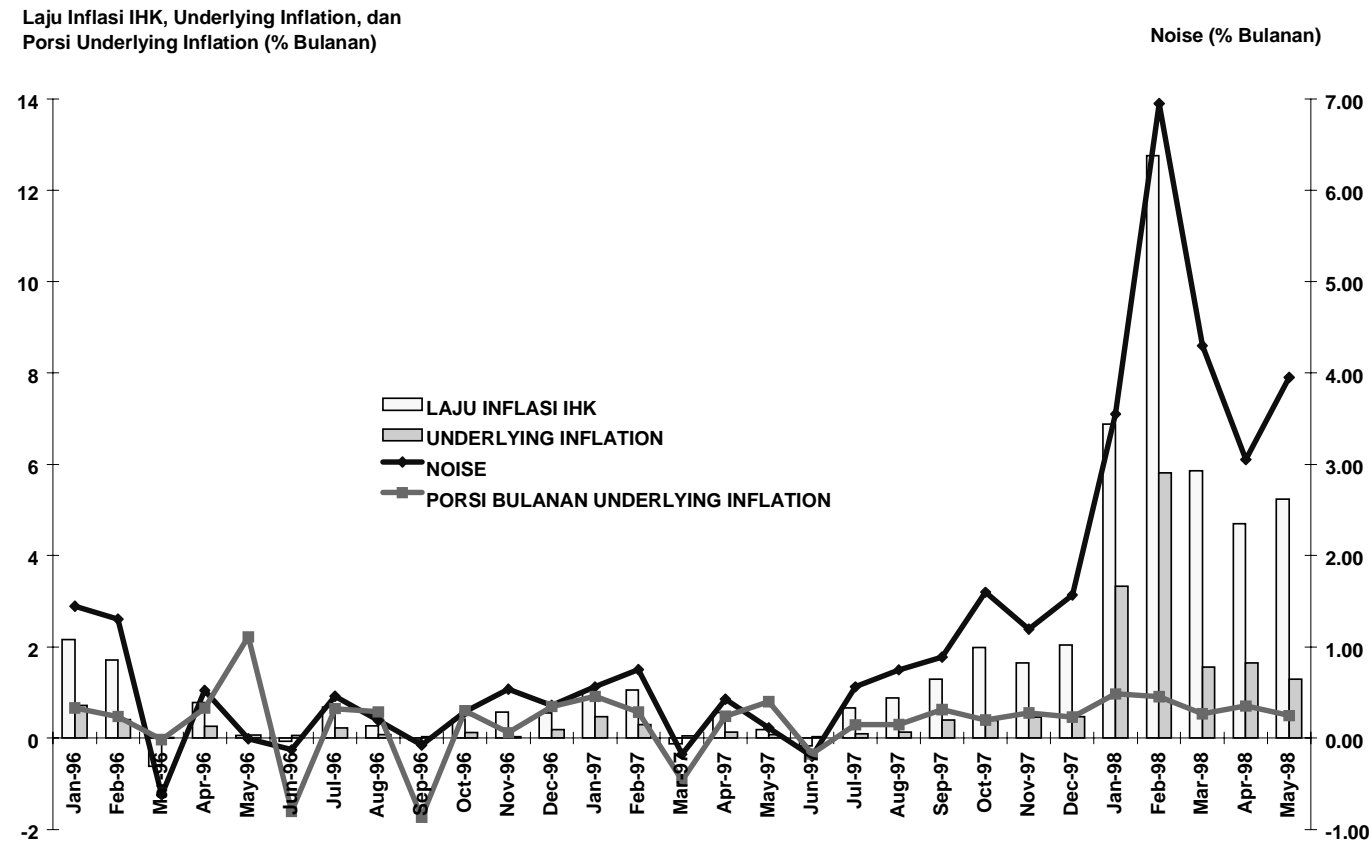

meningkatnya biaya operasional yang dikarenakan oleh berkurangnya pasokan barangbarang. Perkembangan yang terjadi pada sisi produksi dan distribusi tersebut, selanjutnya menyebabkan meningkatnya porsi noise dalam inflasi IHK.

Menilik beberapa fakta mengenai inflasi IHK, komponen permanen, dan noise-nya menunjukkan bahwa inflasi IHK sampai dengan bulan Mei tahun kalender 1998 telah mencapai kumulatif bulanan sebesar 35.44\%, sedangkan underlying inflation (inflasi sisi permintaan) mencapai sekitar $13.64 \%$, dan unsur noise melaju sebesar $21.80 \%$ (Grafik 2$)^{25}$. Jika dilihat dari porsinya terhadap inflasi $\mathbb{H K}$, porsi underlying inflation telah mengalami penurunan yang cukup tajam dari 48\% di bulan Januari menjadi 25\% di bulan Mei 1998, sedangkan porsi noise meningkat dari 52\% di bulan Januari menjadi 75\% (Grafik 2) .

Selanjutnya, dari sisi kecenderungan jangka pendeknya, inflasi IHK masih menunjukkan kecenderungan untuk tetap tinggi dan belum stabil. Hal ini terutama disebabkan oleh perilaku noise yang masih bergejolak pada laju yang tinggi (Grafik 2). Beberapa sub-komoditi dalam laju inflasi IHK yang menyumbang pada perilaku noise tersebut adalah kelompok komoditi:

1. Minuman non alkohol

2. Tembakau dan minuman beralkohol

25 Angka-angka ini adalah angka sum cummulative yang menjumlah laju inflasi bulanan dari bulan Januari sampai dengan Mei 1998. 
3. Lemak dan minyak

4. Sayur-sayuran

5. Padi-padian, Umbi-umbian dan hasil-hasilnya

6. Makanan Jadi

7. Biaya tempat tinggal

8. Bahan bakar, penerangan, dan air

9. Transportasi

Dilain pihak, perilaku underlying inflation terlihat cenderung menurun dan akan kembali pada stabilitas jangka pendeknya ketika sebelum krisis moneter. Walaupun demikian, masih terdapat indikasi adanya tekanan dari sisi permintaan agregat yang cukup persistent, yang ditunjukkan oleh angka underlying inflation yang masih tinggi yaitu 1.65\% di bulan April dan 1.29\% di bulan Mei 1998 (Grafik 2) .

Beberapa hipotesa yang diajukan dalam kaitannya dengan perilaku noise dan underlying inflation diatas adalah bahwa peningkatan yang terjadi pada porsi noise disebabkan oleh paling tidak empat hal yang saling berkaitan.

- Pertama adalah feed-through dari kenaikan harga bahan bakar minyak dan tarif dasar listrik secara langsung ke komponen BBM, Penerangan, dan Listrik yang secara tertimbang merupakan 5.14\% dari total inflasi IHK, dan secara tidak langsung ke harga-harga jasa transportasi yang secara tertimbang membentuk 9.75\% dari total inflasi IHK. Feed-through ini menyebabkan semakin tingginya biaya produksi dan distribusi barang-barang pasokan yang kemudian tercemin dalam laju inflasi.

- Kedua adalah second stage pass-through dari depresiasi dan gejolak nilai tukar yang terjadi

Grafik 3. Kecenderungan IHPB (3 Months Moving Average)

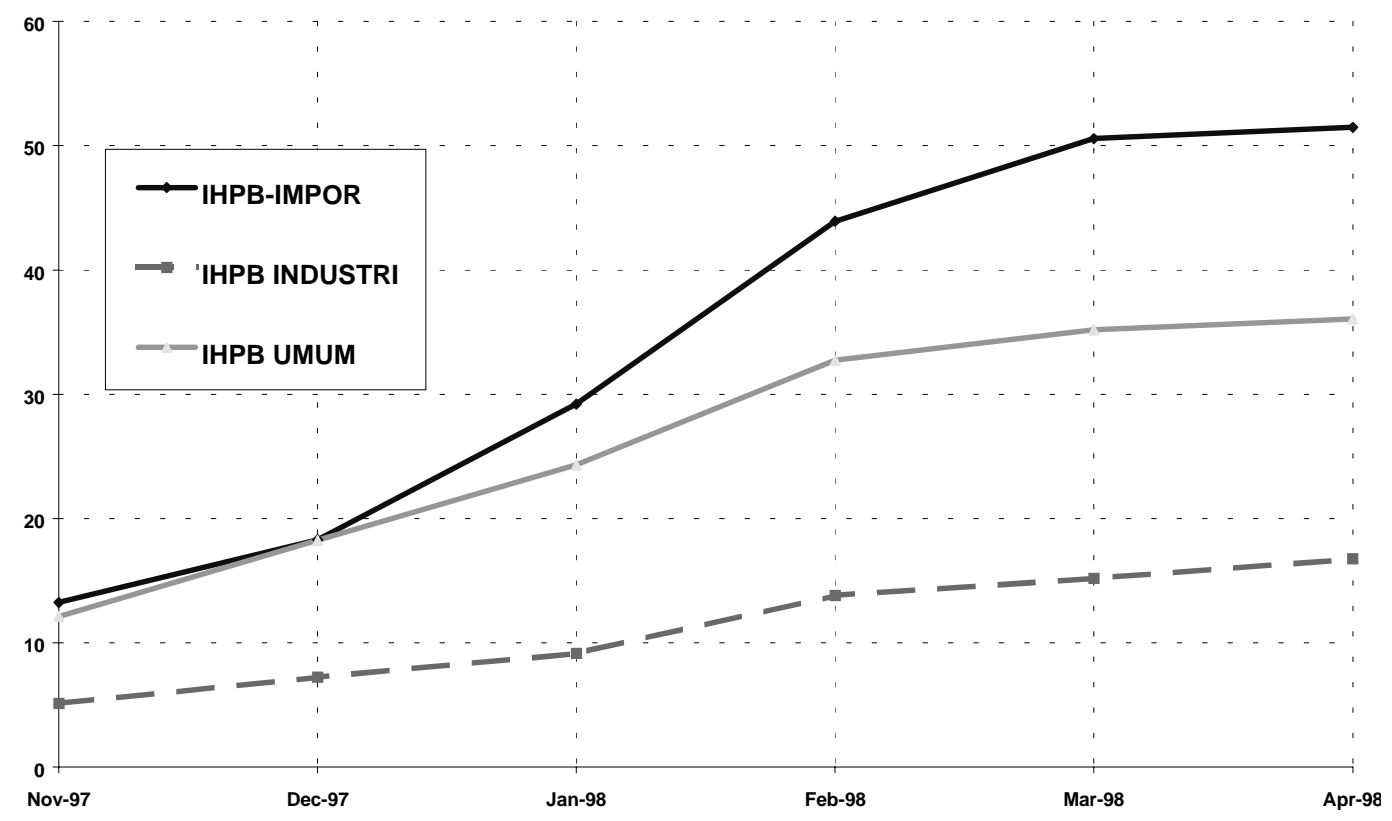


pada sisi distribusi. Sebagaimana telah diyakini, sebagai akibat dari depresiasi nilai tukar dan menurunnya kredibilitas instrumen pembayaran luar negeri Indonesia, maka telah terjadi peningkatan biaya akuisisi barang imput produksi maupun barang impor siap jual orer-thedodk (sampai di pelabuhan bongkar muat). Peningkatan biaya akuisisi over-the-dbdk tersebut jika ditambah dengan kenaikan harga bahan bakar minyak, tarif dasar listrik, dan biaya transportasi, akan diterjemahkan sebagai meningkatnya biaya persediaan (inventory) per unit pada kegiatan di sisi produksi dan total biaya operasi domestik di sisi distribusi (domestic wholesaler's dan retailer's cost). Efek bersih dari meningkatnya biaya inventory dan operasional tersebut adalah meningkatnya harga jual produsen dan mark-up distributor yang kemudian tercemin dalam laju inflasi. Peningkatan yang terjadi pada harga jual produsen dan mark-up distributor tersebut selanjutnya dapat dilihat pada kecenderungan perubahan harga-harga perdagangan besar (IHPB) yang masih meningkat, khususnya untuk IHPB di sektor industri, sebagaimana yang dapat dicemati pada Grafik 3.

- Ketiga adalah terganggunya kelancaran distribusi barang-barang pasokan sebagai akibat dari kerusuhan yang terjadi di beberapa kota dagang utama di Pulau Jawa dan Sumatera. Kerusuhan-kerusuhan yang terjadi pada bulan April dan Mei 1998 tersebut telah menyebabkan rusaknya jaringan distribusi, baik itu dalam bentuk kerusakan infrastruktur maupun berkurangnya sumber-daya kewirausahaan di sektor distribusi. Data rekapitulasi kerusakan di lima kota besar yang dilanda kerusuhan terhebat, yaitu: Jakarta, Surakarta, Lampung, Medan, dan Palembang menunjukkan bahwa secara total terdapat sekurangnya 7300 tempat usaha yang dirusak oleh para perusuh dan penjarah. Tempat-tempat usaha tersebut merupakan infrastruktur yang penting bagi kelancaran distribusi, seperti shopping center, toko-toko retail, rumah toko, dan pasar swalayan. Dari sisi sumber daya manusia, media masa telah melansir bahwa disaat terjadi kerusuhan dan beberapa hari sesudahnya, sudah sekitar 10,000 orang WNI keturunan Cina yang sebagian besar adalah wirausahawan yang berbisnis di sektor perdagangan dan jasa pergi meninggalkan Indonesia. Kiranya dapat diperkirakan bahwa trauma psikologis yang ditimbulkan oleh kerusuhan akan cenderung menurunkan minat para wirausahawan tersebut untuk kembali berusaha di Indonesia. Arus eksodus dan kerusakan pada infrastruktur distribusi diatas telah menyebabkan berkurangnya kelancaran pasokan barang-barang hasil produksi di kota-kota yang dilanda kerusuhan. Hal ini berakibat pada peningkatan laju inflasi IHK, khususnya noise inflation. Selanjutnya, karena bobot dari kota-kota utama tersebut dalam perhitungan inflasi nasional cukup besar, yaitu kurang lebih 47\% dari total inflasi IHK nasional, maka nise yang terjadi di kota-kota tersebut akan secara signifikan mempengaruhi perhitungan inflasi secara nasional.

- Akhirnya, hal keempat yang menyumbang pada noise inflation adalah adanya ekspektasi pengusaha bahwa perekonomian nasional akan diwarnai oleh penurunan permintaan secara agregat. Ini dapat dilihat dari hasil saldo bersih tertimbang Survey Kegiatan Dunia Usaha (SKDU) di Triwulan I / 1998 yang menunjukkan melemahnya persepsi pengusaha terhadap masa depan perekonomian (Grafik 4).

- Seiring dengan melemahnya persepsi pengusaha tersebut, terdapat indikasi bahwa untuk menjamin laba perusahaan tidak akan terpukul oleh krisis moneter, maka kebijakan kenaikan harga yang diiringi oleh pengurangan biaya produksi melalui pengurangan output dan variable cost (biaya buruh) melalui PHK, adalah langkah yang akan banyak dilakukan oleh pengusaha untuk mengambil pendapatan marjinal (marginal revenue) yang seoptimal mungkin sebelum produksi harus secara permanen dikurangi atau dihentikan sama sekali. Dapat 
Grafik 4. Saldo Bersih Tertimbang Hasil SKDU

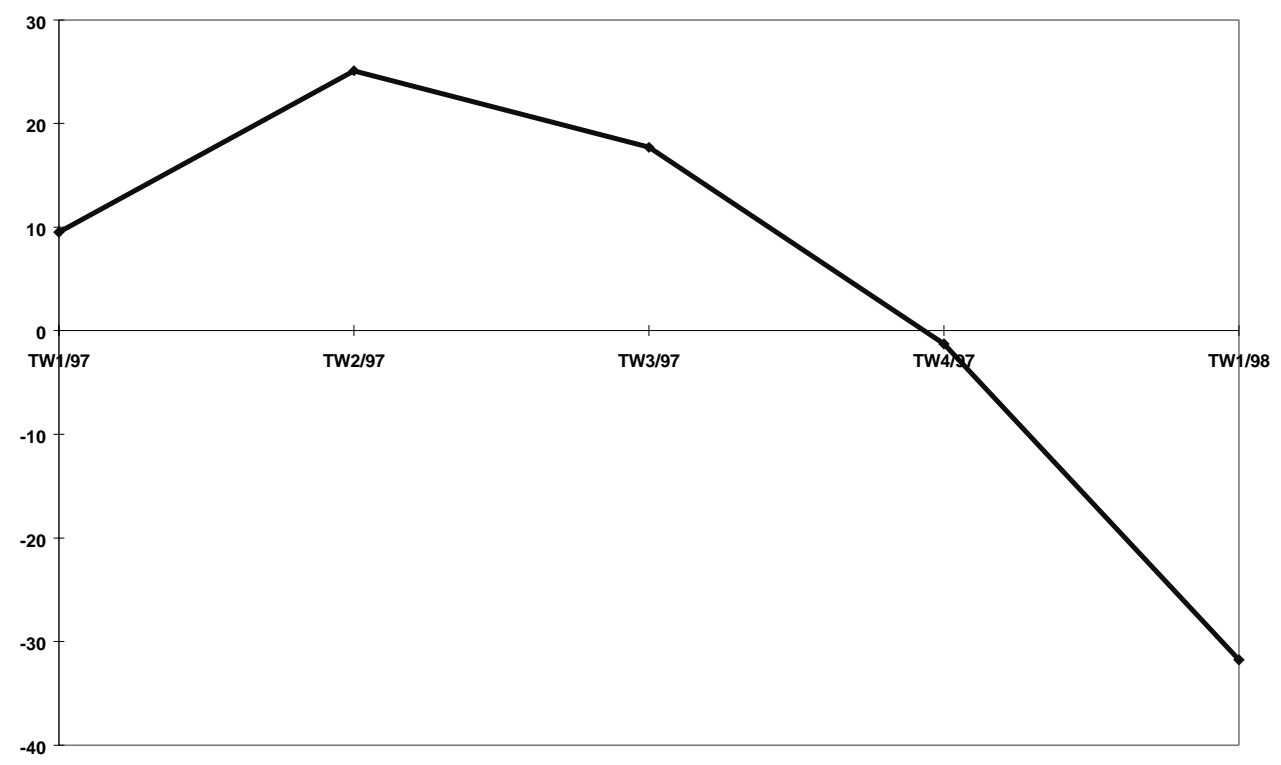

Grafik 5. Hasil SKDU Mengenai Kebijakan Pengusaha di Sisi Harga, Produksi, dan Variable Cost Menurut Sektor

(Saldo Bersih ${ }^{26}$ )

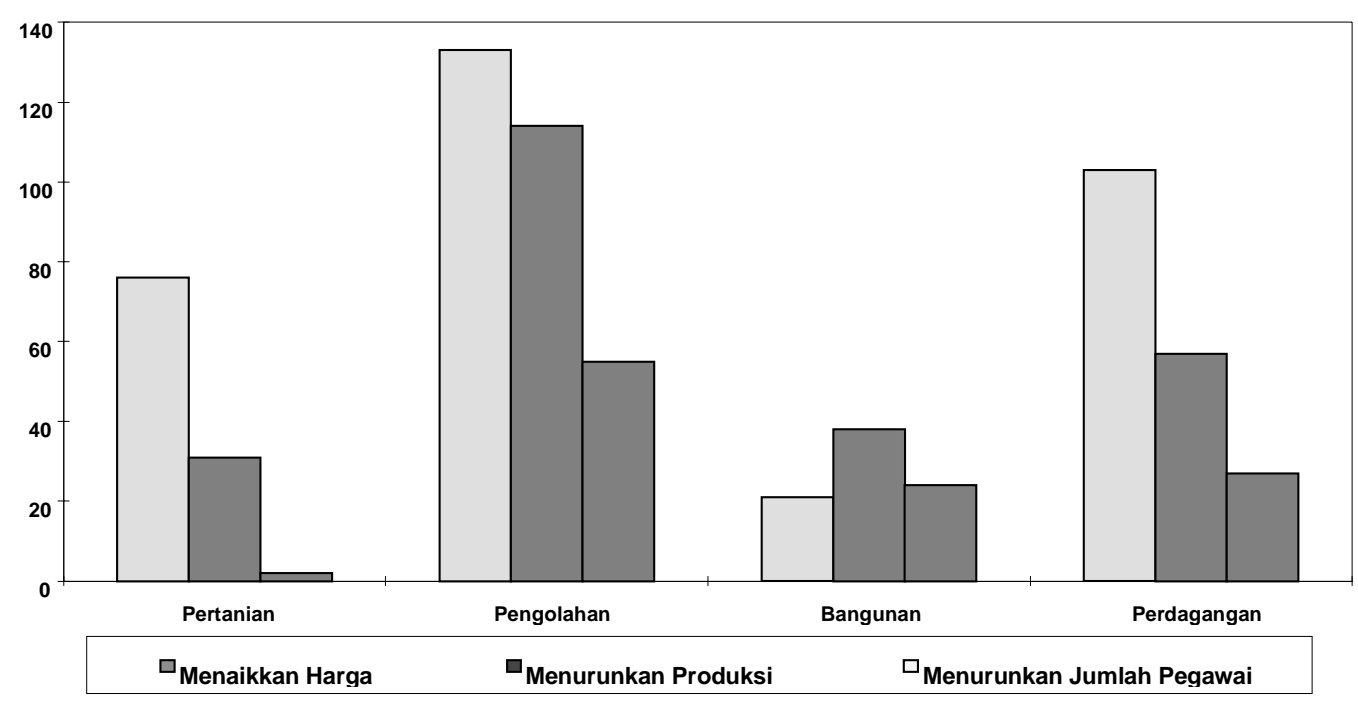

26 Saldo bersih yang positif berarti jumlah pengusaha yang menjawab bahwa harga jual akan dinaikkan, produksi akan diturunkan, dan PHK akan dilanjutkan lebih banyak dari pada yang menjawab sebaliknya. Khusus untuk sektor bangunan dan perdangan saldo bersih jumlah perusahaan yang menyatakan akan menurunkan produksi diambil dari saldo bersih jumlah perusahaan yang menyatakan bahwa barang hasil produksinya tidak laku terjual. 
dilihat pada Grafik 5 dibawah bahwa di Triwulan I / 1998 secara net jumlah pengusaha yang menyatakan akan meningkatkan harga jual, menurunkan produksi, dan menurunkan jumlah pegawai telah meningkat diatas jumlah pengusaha yang menyatakan sebaliknya.

Berdasarkan pengamatan diatas terlihat bahwa dalam periode eskalasi krisis moneter, yaitu dari bulan Januari sampai Mei 1998 faktor-faktor yang menjadi penyebab gejolak temporer pada inflasi (noise) adalah faktor-faktor yang dominan berpengaruh pada laju inflasi IHK. Pada sisi underlying inflation dilain pihak terdapat indikasi kuantitatif yang cukup kuat yang menunjukkan bahwa meningkatnya porsi underlying inflation di bulan Januari dan Februari 1998 adalah sepenuhnya karena faktor ekspektasi yang disambut oleh ekses likuiditas dalam perekonomian. Dalam hal ini meningkatnya permintaan dalam masyarakat adalah karena konsumen melihat besarnya unsur noise dalam inflasi IHK yang selanjutnya diterjemahkan menjadi rush buying untuk melindungi ekses likuiditas yang ada ditangan mereka setelah terjadi bank run. Oleh karena itu, meningkatnya underlying inflation sebenamya tidak akan material bila di tidak terdapat ekses likuiditas dan di sisi produksi dan distribusi tidak terdapat banyak sinyal-sinyal noise seperti kelangkaan pasokan barang-barang (supply shortage) dan meningkatnya harga jual di tingkat distributor (second stage pass through) ${ }^{27}$. Ketika ekses likuiditas dapat diserap kembali ke dalam sistem moneter, maka sinyal-sinyal noise yang pada hakekatnya sudah berkepanjangan, walaupun meningkatkan ekspektasi inflasi tetap tumpul sebagai pemicu meningkatnya underlying inflation.

Akhirnya, berdasarkan kejadian-kejadian diatas dapat ditarik suatu benang merah bahwa dalam kaitannya dengan kebijakan moneter, maka dengan terekskalasinya krisis moneter, dapat dikatakan bahwa laju inflasi IHK cenderung menjadi anchor yang kurang baik bagi kebijakan vis avis underlying inflation. Selanjutnya dalam kaitannya dengan noise dalam inflasi $\mathbb{H K}$, stabilisasi unsur noise tersebut secara teoritis berada diluar jangkauan kebijakan moneter oleh Bank Indonesia, apalagi setelah dikeluarkannya kebijakan sistem nilai tukar freely floating. Oleh karena itu, dapat disimpulkan bahwa kebijakan untuk menurunkan inflasi dalam krisis moneter harus dilakukan dari berbagai arah, yaitu: (a) menyerap kelebihan likuiditas dalam masyarakat melalui kebijakan suku bunga untuk menahan underlying inflation agar tidak material dalam memicu inflasi IHK yang lebih besar lagi, dan (b) mengurangi gejolak noise yang berkepanjangan dalam inflasi IHK melalui kebijakan-kebijakan industrial untuk memperlancar dan mendorong kegiatan produksi dan distribusi di sektor rill, dan mengurangi rentanitas struktur mikro-fundamental terhadap gejolak ekstemal yang berkelanjutan (krisis nilai tukar), serta (c ) upaya stabilisasi nilai tukar

\section{Kesimpulan}

Interaksi yang semakin dinamis dalam perekonomian internasional dan domestik telah menyebabkan pengendalian inflasi melalui pengendalian uang beredar menjadi lebih kompleks dan mengharuskan Bank Indonesia untuk memiliki suatu indikator harga yang relevan dengan kebijakan moneter. Selama ini Bank Indonesia sangat bergantung pada

27 Lihat Lampiran 1. 
laju inflasi IHK untuk memonitor efektifitas kebijakan moneternya. Walaupun demikian, terdapat permasalahan dengan indikator ini yaitu adanya unsur noise yang menggangu judgement kebijakan moneter.

Penelitian indeks harga yang relevan dengan kebijakan moneter yang telah dilakukan oleh Bank Indonesia menunjukkan bahwa terdapat beberapa indikator harga selain laju inflasi IHK yang dapat dijadikan anchor untuk pengendalian inflasi melalui pengelolaan jumlah uang beredar. Indikator-indikator harga tersebut adalah laju inflasi kelompok inflasi food \& energy, PDB deflator, inflasi non-administered, inflasi non-traded, dan underlying inflation. Namun, mengingat terdapat sensitifitas yang cukup tinggi antara inflasi food \& energy dan faktor-faktor yang menyebabkan adanya noise dalam inflasi IHK, maka indikator ini masih dapat menggangu judgement kebijakan moneter. Lebih daripada itu, terdapat overlapping yang cukup besar antara inflasi non-administered dan non-traded dengan underlying inflation, dimana kebanyakan dari barang-barang yang membentuk underlying inflation dapat pula dikategorikan sebagai inflasi non-administered dan non-traded. Selanjutnya dalam kaitannya dengan ekskalasi krisis moneter dan dampaknya terhadap inflasi IHK, terlihat bahwa underlying inflation adalah anchor yang lebih cocok untuk menilai efektifitas kebijakan moneter. Demikian halnya karena dengan terekskalasinya krisis moneter, laju inflasi IHK cenderung lebih dipenuhi oleh nise yang dapat mengganggu judgement kebijakan moneter. Oleh karena itu underlying inflation adalah indikator harga yang lebih relevan dengan kebijakan moneter.

\section{Saran}

Sebagai penutup, dapat disarankan disini untuk suatu penelitian lebih lanjut mengenai sumbangan struktur fundamental mikroekonomi nasional terhadap inflasi. Kajian terutama diarahkan untuk memperoleh gambaran mengenai struktur, perilaku, dan kinerja fundamental mikroekonomi nasional dan rentanitasnya terhadap gejolak eksternal seperti depresiasi dan gejolak yang berkelanjutan pada nilai tukar. Dengan melakukan kajian yang lebih mendalam mengenai fundamental mikroekonomi tersebut, diharapkan akan lebih memperjelas proses pembentukan harga di sektor riil, terutama dalam kaitannya dengan pembentukan noise inflation dan dampaknya terhadap tekanan inflasi agregat dalam perekonomian.

Selanjutnya dalam kaitannya dengan pembahasan mengenai peran underlying inflation dalam kerangka kerja rezim inflation targeting perlu dikaji aspek teoritis mengenai penetapan laju inflasi sebagai sasaran kebijakan moneter ${ }^{28}$. Premis yang mendasari inflation targeting adalah bahwa tujuan akhir dari kebijakan moneter hanyalah ditujukan untuk mencapai dan mempertahankan laju inflasi yang rendah dan stabil. Dalam konteks ini

28 Diskusi mengenai kaitan antara underlying inflation dan inflation targeting dapat dilihat di Masson R. Paul, Savastano, Miguel A., dan Sharma, Sunil, 1997. The Scope of Inflation Targeting in Developing Countries. IMF Working Paper, Agustus; Debelle, Guy, 1997. Inflation Targeting in Practice. Economic Research Department, RBA, December; De Brouwer, Gordon, dan O'Regan, James, 1997. Evaluating Simple Monetary Policy Rules for Australia. RBA, Conference on Monetary Policy and Inflation Targeting, July; Haldane, Andrew G, 1997. Designing Inflation Target. RBA, Conference on Monetary Policy and Inflation Targeting, July ; Grenville, Stephen, 1997. The Evolution of Monetary Policy: From Money Targets to Inflation Targets. RBA, Conference on Monetary Policy and Inflation Targeting, July. 
diasumsikan bahwa (1) laju inflasi yang tinggi adalah suatu bentuk biaya yang harus ditanggung oleh perekonomian berupa pertumbuhan ekonomi yang rendah dan menurunnya nilai riil dari pendapatan nasional, (2) kebijakan moneter, dalam hal ini kebijakan pengendalian uang beredar, tidak dapat mempengaruhi pertumbuhan output dalam jangka panjang, tapi dapat dalam jangka pendek, sedangkan (3) pengendalian inflasi melalui kebijakan moneter adalah dalam rangka stabilisasi dan penurunan laju inflasi dalam jangka panjang dan bukan dalam jangka pendek. Oleh karena itu masih diperlukan suatu analisa mengenai benefit dan cost dari disinflationary policy oleh bank sentral, terutama dalam kaitannya dengan autout variability yang inheren dalam skim inflation tergeting.

Disamping itu, beberapa prasyarat dari stabilisasi dan penurunan laju inflasi melalui penetapan inflasi sebagai sasaran tunggal mengharuskan adanya independensi bank sentral dalam melaksanakan kebijakan moneter, ditiadakannya sasaran pengendalian nilai tukar, adanya suatu kisaran nominal anchor berupa indeks harga yang relevan sebagai sasaran, adanya suatu metodologi proyeksi inflasi yang dapat menangkap prospek inflasi di masa datang dengan baik, dan prosedur operasional kebijakan moneter yang forward-looking. Dengan kelima syarat diatas terlihat bahwa setidaknya dua syarat telah secara formal dipenuhi oleh Bank Indonesia yaitu adanya independensi dalam kebijakan moneter dan sistem nilai tukar yang freely floating. Dari segi teknis pelaksanaannya, penelitian mengenai underlying inflation sebagai indeks harga yang relevan dengan kebijakan moneter, sedikit banyak telah memperjelas arah dalam mendesain arsitektur dari skim inflation targeting untuk Indonesia. Walaupun demikian masih perlu untuk diestimasi lebih lanjut philips arve Indonesia dan kaitannya dengan kebijakan moneter melalui pengendalian uang beredar. Lebih dari pada itu proyeksi ekpektasi inflasi dalam jangka menengah juga masih diperlukan untuk bisa menjadi masukan bagi program moneter yang forward looking oleh Bank Indonesia.

\section{Lampiran 1}

\section{Perilaku Inflasi Ditengah Krisis Moneter}

- Untuk memilah-milah perbedaan perilaku inflasi disaat 'nomal' maupun 'krisis', telah dilakukan uji ekonometri dengan menggunaan persamaan-persamaan jangka pendek berikut:

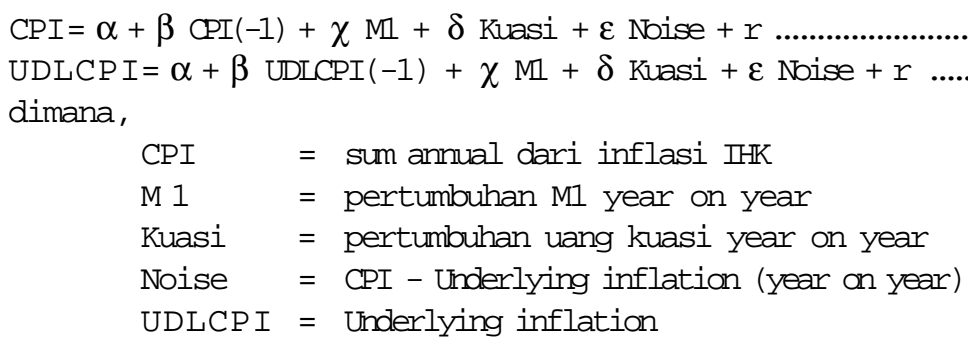

- Uji statistik terhadap persamaan diatas dilakukan setelah sebelumnya dilakukan uji kointegrasi antara level CPI, dengan level uang kartal, giral, dan kuasi. Hasil dari uji kointegrasi tersebut dapat dilihat pada grafik dan statistik berikut ini: 
Grafik 1. Perilaku Level CPI, Uang Kartal, Uang Giral, dan Uang Kuasi

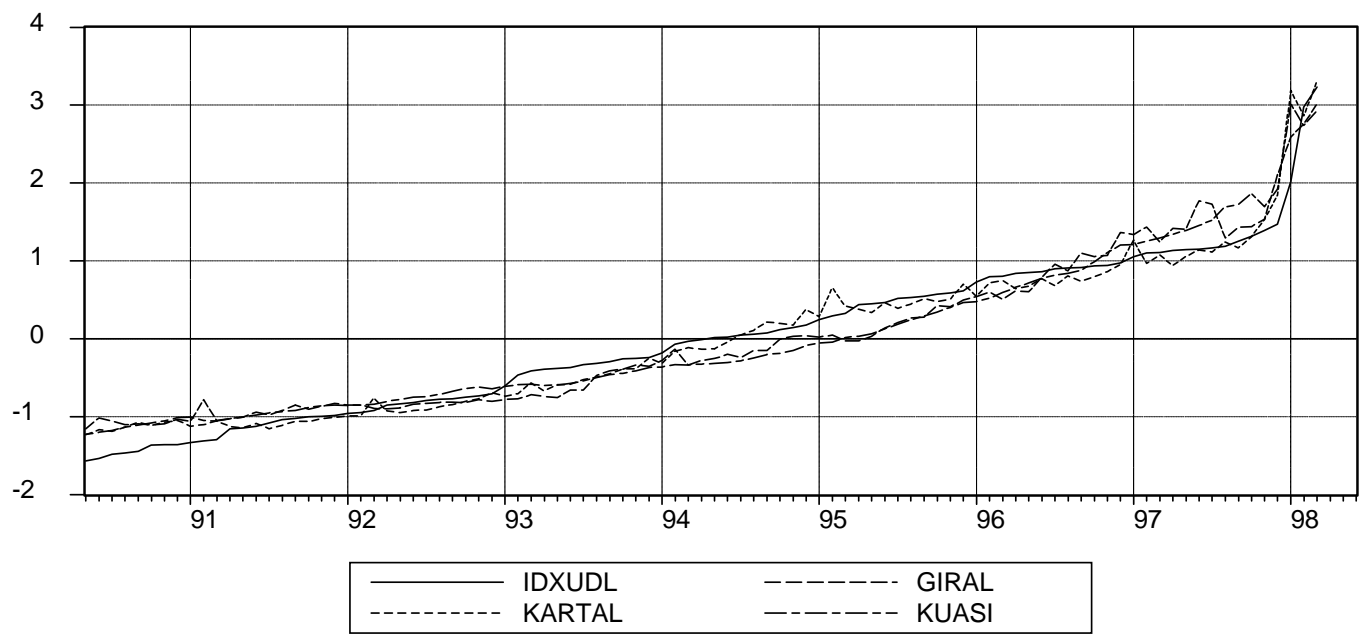

Hasil Johansen Cointegration Test

Sampel Data Bulanan: 1990:05 1998:06

Series: IDXUDL KARTAL GIRAL KUASI

Lags interval: 1 to 2

$\begin{array}{lllll} & \text { Likelihood } & 5 \text { Percent } & 1 \text { Percent } & \text { Hypothesized } \\ \text { Eigenvalue } & \text { Ratio } & \text { Critical Value } & \text { Critical Value } & \text { No. of CE(s) }\end{array}$

$\begin{array}{lllll}0.040828 & 3.876686 & 3.76 & 6.65 & \text { At most } 3 \text { * }\end{array}$

* $(* \star)$ menunjukkan penolakan hipotesa non-kointegrasi pada 5\% (1\%) significance level

- Selanjutnya dari hasil analisa ekonometri terhadap perilaku inflasi dengan: menggunakan model persamaan diatas, dan memilah periode observasi menjadi sebelum krisis nilai tukar, saat krisis nilai tukar (periode sampai dengan Desember 1997), dan saat krisis makro moneter (periode sampai dengan Maret 1998), maka hasil regresi dapat di rekapitulasi dalam rekapitulasi berikut ini:

Inflasi IHK 


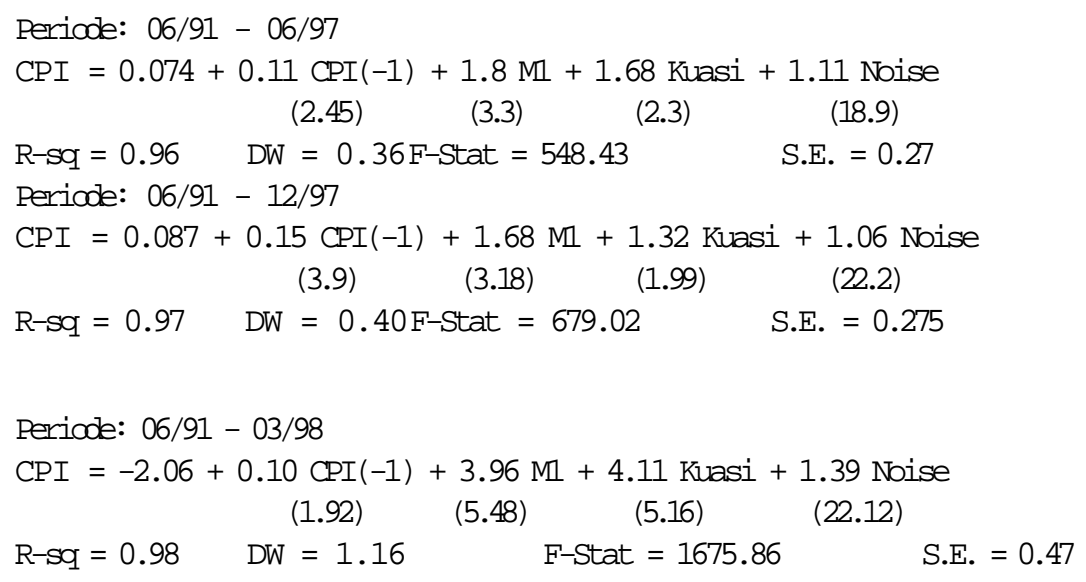

Underlying Inflation

Periode: 06/91 - 06/97

$\operatorname{UDLCPI}=0.074+0.8 \operatorname{UDLCPI}(-1)+0.09 \mathrm{MI}+0.12$ Kuasi +0.05 Noise

$\begin{array}{ccccc} & (11.10) & (0.24) & (0.26) & (2.49) \\ \text { R-Sq }=0.82 & \text { DW }=1.24 & \text { F-Stat }=82.20 & \text { S.E. }=0.17\end{array}$

Periode: $06 / 91-12 / 97$

$\mathrm{UDLCPI}=0.006+0.76 \operatorname{UDLCPI}(-1)+0.17 \mathrm{MI}+0.23$ Kuasi +0.07 Noise
(12.4)
(0.48)
(0.55)
(4.03)

$\mathrm{R}-\mathrm{Sq}=0.83$

$\mathrm{DW}=1.16 \quad$ F-Stat $=96.60$

S.E. $=0.17$

Periode: $06 / 91-03 / 98$

UDLCPI $=-1.76+0.50 \operatorname{UDLCPI}(-1)+2.62 \mathrm{MI}+3.4$ Kuasi +0.27 Noise
(1.92)
(5.48)
(5.16)
(22.12)

$\mathrm{R}-\mathrm{sq}=0.94$

$\mathrm{DW}=1.69$ F-Stat $=324.44$

S.E. $=0.39$

\begin{tabular}{|c|c|c|c|}
\hline Merujuk pada hasil rekapitulasi diatas maka & disusun matriks befikut: \\
Tabel 2. Matriks Variabel & Variabel Independen & vang Secara Statist & Signifikan Terhadan \\
\hline Laju Inflasi IHK dan Underl|ying Inflation Berdaparkan Peringkat & & \\
& Periode I & Periode II & Periode III \\
& $06 / 91-06 / 97$ & $06 / 91-12 / 97$ & $06 / 91-03 / 98$ \\
\hline Laju Inflasi IHK & M 1 & M 1 & Uang Kuasi \\
& Uang Kuasi & Uang Kuasi & M 1 \\
& Noise & Noise & Noise \\
& Ekspektasi & Ekspektasi & Ekspektasi \\
\hline
\end{tabular}

$\begin{array}{llll}\text { Laju Underlying } & \text { Ekspektasi } & \text { Ekspektasi } & \text { Noise }\end{array}$

29 Peringkat disusun sesuai dengan hasil koefisien regresi, sedangkan signifikansi diukur dengan T-Statistik. Pada matriks diatas hanya ditampilkan variabel-variabel independen yang signifikan pada tingkat $90 \%$ keyakinan. 
Inflation

M 1

Uang Kuasi

Ekspektasi

- Beberapa hal yang dapat ditangkap dari matriks diatas adalah bahwa sampai dengan periode pertama dari krisis moneter, yaitu sampai dengan bulan Desember 1997, terlihat dalam jangka pendek laju inflasi sisi permintaan agregat (underlying inflation) masih lebih banyak dipengaruhi oleh ekspektasi terhadap laju perubahan harga-harga di masa depan. Dilain pihak, untuk perilaku laju inflasi IHK sampai dengan periode ke-dua dari krisis moneter, yaitu ketika krisis nilai tukar sudah mulai berkembang menjadi krisis makro moneter (triwulan I / 1998), faktor-faktor yang menjelaskannya tidak berubah dari sebelum krisis nilai tukar terjadi, yaitu: uang beredar, noise, dan ekspektasi. Hal ini menunjukkan bahwa uang beredar merupakan potensi yang dapat mendorong inflasi di sisi permintaan dalam jangka pendek, akan tetapi jika tidak ada faktor-faktor pemicu seperti menurunnya produksi dan distribusi sehingga terjadi kelangkaan pasokan barang, maka uang beredar tidak material sebagai penyebab tekanan inflasi sisi pemintaan.

- Berkaitan dengan hal diatas, kiranya dapat dicermati bahwa ketika krisis moneter sudah semakin terekskalasi terlihat bahwa faktor-faktor yang mempengaruhi laju underlying inflation tidak hanya ekspektasi, tapi meluas kepada jumlah uang beredar dan noise. Fenomena ini memberi indikasi bahwa pada triwulan I / 1998 faktor noise, yang dapat diterjemahkan sebagai komplikasi dari iklim ketidakpastian usaha dan naiknya biaya input yang mengganggu proses produksi dan distribusi, yang timbul bersamaan dengan meningkatnya ekspektasi masyarakat terhadap laju inflasi telah mentransformasi potensi inflatoir dari ekses likuiditas menjadi inflasi yang material.

\section{Lampiran 2}

Pengujian 'Random Walks' Pada Laju Inflasi IHK dan Komponennya

\section{Metodologi}

Dengan mendefinisikan random walks sebagai perilaku series yang bervariasi terhadap perubahan waktu dan tidak mempunyai batas variance yang tetap, maka pengujian random walks pada laju inflasi IHK adalah pengujian stationarity pada laju inflasi IHK. Jika laju inflasi IHK terbukti non-stationary, maka laju inflasi IHK yang terjadi dengan berjalannya waktu cenderung untuk tidak kembali pada suatu kecenderungan jangka panjang yang sama (random walks). Sebaliknya jika laju inflasi IHK temyata stationary, maka laju inflasi IHK yang terjadi dengan berubahnya waktu akan cenderung kembali pada suatu kecenderungan jangka panjang yang tetap.

Üi stationarity diatas dilakukan dengan melakukan Augmented Dickey Fuller - Test (ADF-Test) terhadap laju inflasi IHK umum dan komponennya (IHK kelompok makanan, perumahan, sandang, dan aneka barang, serta underlying inflation). Tiga bentuk persamaan regresi linear yang digunakan dalam $\mathrm{ADF}$-Test tersebut adalah sebagai berikut:

(Pure Random Walks) $\quad \delta y_{t}=\gamma_{y_{t-1}}+\Sigma \beta_{1} \delta_{y_{t i}}+\varepsilon$ 
(Pure With Drift) $\quad \delta y_{t}=\alpha_{0}+\gamma_{\mathrm{t}_{-1}}+\Sigma \beta_{1} \delta \mathrm{y}_{\mathrm{ti}}+\varepsilon_{\mathrm{t}}$

(Pure With Drift and Trend) $\delta y_{t}=\alpha_{0}+\gamma_{y_{t-1}}+\alpha_{2} t+\Sigma \beta_{1} \delta_{y_{t-1}}+\varepsilon t$...................................... (3)

dimana, $y_{t}$ adalah laju inflasi IHK atau komponennya dan $t$ adalah waktu. Perbedaan yang terdapat pada tiga persamaan regresi diatas menunjukkan keberadaan trend deteministik, yaitu $a_{0}$ dan $a_{2} t$. Persamaan (1) adalah model persamaan 'random walks' murni, persamaan (2) menambah komponen intercept (drift), dan persamaan (3) menambah komponen trend. Parameter yang menjadi perhatian dalam kedua sequence persamaan diatas adalah $g$, dimana jika $g=0$, maka sequence $\left\{g_{t}\right\}$ mengandung unsur random walks. Untuk menguji apakah $g$ secara signifikan berbeda dari nol dilakukan pembandingan antara F-statistik yang diperoleh dari regresi dengan nilai kritikal McKinnon, yang merupakan replikasi dan perluasan dari nilai kritikal yang pertama kali di simulasi oleh David A. Dickey dengan metode Monte Carlo $0^{30}$

Hasil

Dalam pengujian random walks ini digunakan dua periode sampel untuk melihat perbedaan sebelum dan sesudah krisis nilai tukar terjadi. Kedua periode sampel tersebut adalah (1) periode dari bulan Mei 1990 sampai dengan Mei 1997 untuk periode sebelum krisis nilai tukar, dan (2) periode dari bulan Mei 1990 sampai dengan Maret 1998 untuk periode yang memasukkan krisis nilai tukar sebagai in-sample. Hasil-hasil yang diperoleh dari ADF-test dengan menggunakan dua periode sampel yaitu periode sebelum dan sesudah arrency crisis adalah sebagai berikut :

Tabel 1. Hasil Uji ADF terhadap Laju Inflasi IHK dan Komponennya

(ADF F-Statistics)

\begin{tabular}{|c|c|c|c|c|c|c|}
\hline Periode: & $05 / 90$ & $-05 / 97$ & & $05 / 90$ & $03 / 98$ & \\
\hline Persamaan: & Pure & +Drift & +Trend & Pure & + Drift & + Trend \\
\hline IHK & -2.47 & -4.72 & -4.70 & $0.28 *$ & $-0.56^{\star}$ & $-0.61^{\star}$ \\
\hline & $(-1.61)$ & $(-2.58)$ & $(-3.25)$ & $(-1.61)$ & $(-2.58)$ & $(-3.23)$ \\
\hline Makanan & -3.62 & -4.99 & -5.00 & $-1.09 \star$ & $-1.86^{\star}$ & $2.29 \star$ \\
\hline & $(-1.61)$ & $(-2.58)$ & $(-3.25)$ & $(-1.61)$ & $(-2.58)$ & $(-3.23)$ \\
\hline Perumahan & -2.76 & -4.18 & -4.15 & $-1.31 *$ & -2.74 & $-2.42^{\star}$ \\
\hline & $(-1.61)$ & $(-2.58)$ & $(-3.25)$ & $(-1.61)$ & $(-2.58)$ & $(-3.23)$ \\
\hline Sandang & -2.31 & -4.51 & -4.48 & $0.81^{\star}$ & $0.16^{\star}$ & $0.023 \star$ \\
\hline & $(-1.61)$ & $(-2.58)$ & $(-3.25)$ & $(-1.61)$ & $(-2.58)$ & $(-3.23)$ \\
\hline Aneka-Barang & -3.41 & -4.93 & -4.87 & $-1.55^{\star}$ & -2.76 & $-2.67 \star$ \\
\hline & $(-1.61)$ & $(-2.58)$ & $(-3.25)$ & $(-1.61)$ & $(-2.58)$ & $(-3.23)$ \\
\hline Underlying IHK & -2.30 & -4.78 & -4.75 & 2.34 & 2.60 & $2.48^{\star}$ \\
\hline & $(-1.61)$ & $(-2.58)$ & $(-3.25)$ & $(-1.61)$ & $(-2.58)$ & $(-3.23)$ \\
\hline
\end{tabular}

* Menolak hipotesa bahwa g secara signifikan tidak berbeda dari nol (terdapat unsur 
unit root dalam persamaan) sehingga persamaan mengindikasikan adanya perilaku random walks pada series yang diuji. Angka dalam ( ) adalah McKinnon 10 \% Critical Values. Jika nilai absolut dari ADF F-Statistics berada diatas angka McKinnon, maka hipotesa $g=0$ diterima.

Hasil dari pengujian random walks terhadap laju inflasi IHK diatas menunjukkan bahwa untuk periode sampel yang memasukkan krisis nilai tukar sebagai in-sample laju inflasi IHK cenderung berperilaku random walks atau cenderung untuk tidak kembali pada suatu trend jangka panjang yang tetap seperti pada waktu sebelum krisis nilai tukar terjadi. Hal ini ditunjukkan oleh nilai F-Statistics sebelum krisis yang menunjukkan angka-angka absolut diatas nilai kritikal untuk menerima keberadaan random walks pada ketiga sequence persamaan. Setelah krisis nilai tukar terjadi, nilai F-Statistics secara absolut pada sequence persamaan berada dibawah nilai kritikal McKinnon, yang menandakan bahwa g secara signifikan berbeda dari nol sehingga series laju inflasi IHK cenderung untuk mengambil perilaku random-walks setelah krisis nilai tukar bereskalasi.

Adapun hasil dari komponen-komponen IHK menunjukkan bahwa non-stationarity yang terjadi pada series laju inflasi IHK setelah krisis nilai tukar disebabkan oleh perilaku random walks yang terjadi pada harga-harga dari kelompok makanan dan sandang dalam laju inflasi IHK, dan tidak disebabkan oleh kelompok perumahan dan aneka barang. Perbandingan nilai F-Statistics sebelum dan sesudah terjadi krisis nilai tukar menunjukkan diterimanya hipotesa bahwa g secara signifikan berbeda dari nol pada ketiga sequence persamaan di kelompok makanan dan sandang, sehingga dapat dikonfirmasi adanya perilaku random walks pada kedua kelompok tersebut. Sebaliknya untuk kelompok perumahan dan aneka barang, hipotesa keberadaan unsur random walks ditolak pada persamaan pure random walks with drift sehingga perubahan harga-harga pada kedua kelompok ini masih mengikuti pola jangka panjang seperti sebelum krisis nilai tukar terjadi.

Selanjutnya, underlying IHK atau underlying inflation yang menupakan laju inflasi sisi permintaan agregat tampak tidak tenpengaruh oleh adanya krisis nilai tukar. Nilai F-statis tics dari underlying inflation pada dua dari tiga sequence persamaan menolak keberadaan unsur random walks, yaitu persamaan pure random walks dan pure with drift. Hal ini memberi indikasi bahwa demand shock yang terjadi pada dua bulan pertama Triwulan I / 1998 masih bersifat temporer dan masih mungkin untuk dikoreksi melalui kebijakan penyerapan ekses likuiditas

\section{Kesimpulan}

Berdasarkan hasil-hasil dari uji random walks diatas, maka beberapa implikasi temuan dapat diajukan disini:

- Laju inflasi IHK dan komponen kelompoknya, khususnya kelompok makanan dan sandang cenderung mengikuti pola random walks yang inflatoir setelah krisis nilai tukar terjadi dan berekskalasi. Hal ini berarti bahwa dengan berjalannya waktu, kemungkinan besar perubahan IHK bulanan tidak akan kembali ke kecenderungan jangka panjangnya pada saat sebelum krisis, kecuali jika ada fully blown stnuctural policy yang difokuskan untuk mencegah adverse shock dari krisis moneter untuk meninggalkan bekas permanen dalam struktur perekonomian. Kebijakan tersebut selanjutnya harus diarahkan pada 
upaya untuk mendorong kelancaran produksi dan distribusi pada sektor-sektor yang memproduksi makanan dan sandang.

- Iaju underlying inflation tidak secara konklusif mengikuti pola random walks setelah krisis nilai tukar terjadi, ini menandakan bahwa masih mungkin untuk segera mengkoreksi tingginya underlying unflation dengan nomal measure seperti tight money policy. Atau dengan kata lain dapat disimpulkan bahwa jika ada perubahan pada sisi permintaan agregat, maka perubahan tersebut masih akan konsisten dengan shock temporer pada sisi permintaan agregat dan bukan karena pemanent demand shock .

- Selanjutnya, mengingat noise inflation adalah laju inflasi IHK dikurangi dengan underlying inflation, maka dapat dikatakan bahwa random walks pada inflasi IHK lebih disebabkan oleh random walks pada noise inflation karena underlying inflation secara statistik tidak random walks. Dan, noise inflation tersebut terutama datang dari perilaku inflasi kelompok makanan dan sandang yang random walks.

- Akhirnya, dapat pula disimpulkan bahwa jika tidak dikeluarkan suatu kebijakan yang secara struktural dapat mendorong supply side, terutama di sektor pangan dan sandang, maka kemungkinan besar adverse shodk yang sedang terjadi akan meninggalkan bekas permanen pada inflasi untuk waktu yang cukup lama.

\section{Daftar Pustaka}

Bryan, Michael F. dan Cecchetti, Stephen G., 1993. Mbasuring Core Inflation. Federal Reserve Bank of Cleveland, Working Paper No. 9304, Juni.

Debelle, Guy, 1997. Inflation Targeting in Practice. Economic Research Department, $\mathrm{RBA}$, Desember.

De Brouwer, G. dan O'Regan J., 1997. Evaluating Simple Monetary Policy Rules for Australia. RBA, Conference on Monetary Policy and Inflation Targeting, July.

Enders, W. Applied Econometric Time Series. John A. Willey \& Sons, 1995.

Grenville, S., 1997. The Evolution of Monetary Policy: From Money Targets to Inflation Targets. RBA, Conference on Monetary Policy and Inflation Targeting, July.

Haldane, AG., 1997. Designing Inflation Target. RBA, Conference on Monetary Policy and Inflation Targeting, July.

Masson, R. P. dan Savastano M. A., dan Sharma Sunil, 1997. The Scope of Inflation Targeting in Developing Countries. IMF Working Paper, Agustus.

Reserve Bank of Australia, 1994. Measuring Underlying Inflation. Bulletin, Agustus.

Roger, Scott, 1995. Measures of Underlying Inflation in New Zealand, 1981-1995. RBNZ, September. 